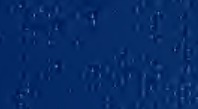




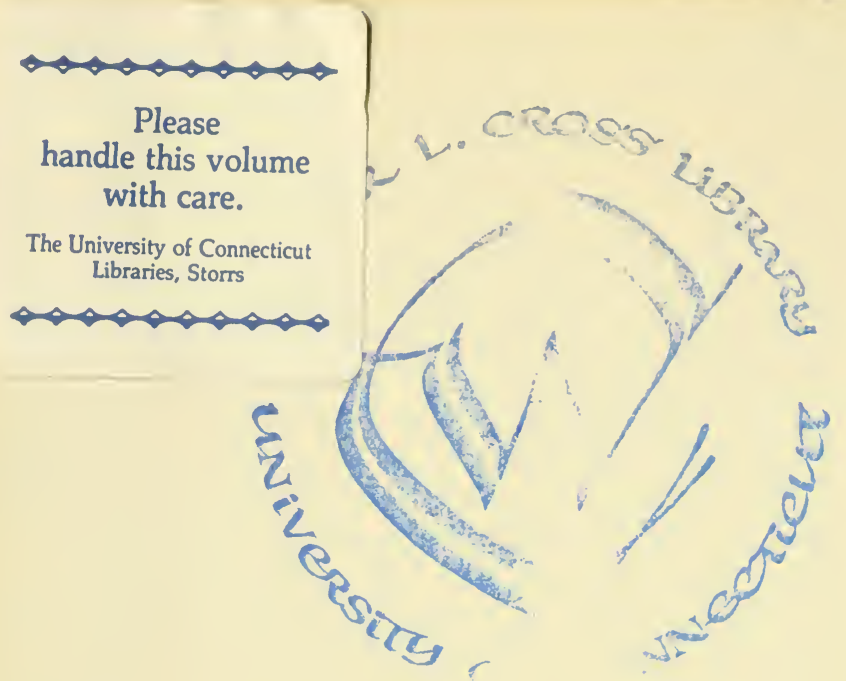

hbl, stx

QK 211.L64 1899

Plantae Selerianae

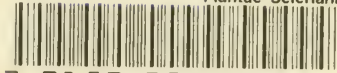

39153007798814 



887 A 6

\section{PLITTE SELERIIIE}

\section{Die von In Edwa nnimidud Frau Cæcilie SELER}

in MEXICO und CENTRALAMERICA gesammelten Pflanzen.

Unter Mitwirkung von Fachmännern veröffentlicht

$$
\text { ron }
$$

Th. LOESENEP

TIRÉ A PART

du Bulletin de l'Herlier Boissier

Vol. VII. No 7 et 8. 1899.

GENÈVE

IMPRINERIE ROMET, 26, BOULEVARD DE PLAINPALAIS 

Extrait du Bulletin de l'Ilerbier Boissier.

Tome VII. No 7. Juillet 1899.

\section{PLANTAE SELERIANA}

\section{Die von D $^{r}$ Eduard SELER und Frau Cæcilie SELER}

in MEXICO und CENTRALAMERICA gesammelten Pflanzen

Unter Mituirkung von Fachmännern veröffentlicht

von

TH. LCESENEß.

III

Im Jahre 189: unternahm Dr. Ed. Seler eine zweite Reise nach Mexico und Centralamerika, abermals in Begleitung seiner Frau Caecilie. Es handelte sich diesmal vornehmlich um die Erforschung der Südprovinzen 0axaca und Chiapas, sowie um die des benachbarten Staates Guatemala, der in seiner ganzen Ausdehnung von der Westgrenze bis zur Ostgrenze in das Gebiet der Republik Honduras hinein durchreist wurde. Der ursprünglich gehegte Plan, auch die Halbinsel Yucatan zu erforschen, musste wegen eines heftigen Fieberanfalles von dem Dr. Seler selbst heimgesucht wurde, aufgegeben werden. Die Reise dauerte rom Herbst 189ב̈ bis Frühjahr 1897 und nahm folgenden Weg: Von der Grenzstation Nuevo Leon über Honterey mit der Bahn nach Mexico, von hier Ausflug nach Patzcuaro über Acámbaro, dann nach 0 axaca, von wo aus eine dreiwöchentliche Tour durch die Mixteca (Nochistlan, Teposcolula, Tláxiaco) unternommen wurde, darauf hinab nach Tehuantepec und weiter über Juchitan nach Tonalá im Staate Chiapas, von hier nörd-

1 Vergl. Bull. Herb. Boiss. II, pag. 5̈33-5̈66 u. III, pag. 609-629. 
lich über den hier Sierra de los Quelenes genannten Teil der sierra Madre nach Cintalapa und in ungefähr östlicher Richtıng iiber die neue llamptstadt Tuxtla Gutierrez nach Chiapa selbst, ferner nach S. Cristobal das seiner IV̈̈rde als Hauptstadt dieses States vor kurzem verlustig gegangen ist, und in nordöstlicher Richlung nach ()cozingo, sodann direkt südlich nach Comitan und in südïstlicher Richtung ïber die Grenze, die in der Nähe der altindischen Ansiedlungen von Tepancuapan überschritten wurde, zu den Ruimen von dem auch in hotanischer Ilinsicht äusserst interessanten und bisher umr wenig erforschten Chacula in Guatemala. mit Besuch des Lrwaldes bei Valambohoch, weiter über Venton, Jacaltenango nach Chiantla und über Santa Cruz Quiche nach der llauptstadt finatemala. Von hier aus wurden mehrere kleinere lieisen ausgefülırt und ler Weg von Guatemala nach Chacula noch einmal zurück gemacht. Dahei wurden z. T. wiederlıolt folgende Orte passiert : Antigua, S. Lucia, sïdwestlich. Solola, Tecpam Guatemala, Totonicapam, Quezaltenango, westlich von Guatemala gelegen. Jer weitere Verlanf der Reise führt uns, nördlich von der llauptstadt, über Salamá nach Coban, und von Salamá östlich über S. Agustin Acasaguastan nach Zacapa, damn den Rio Motagua aJwärts bis Quiriguá, zurück nach Za capa, in südlicher lichtung nach Chiquimula, von hier nach Osten über die Grenze nach Copan in der Republik II onduras, zurïck in südwestlicher Richtung nach Esquipulas und Ipala in Fuatemala. Auf dieser Tour erfulur die Reise infolge Ir. Selers Erkiankung ihren Alsschluss. Sie kehrten zurück nach Guatemala um dann von San José am Stillen Ocean zu Schiff nach llanzanillo an der mexicanischen Küste und ron hier über Colima, Guadalajara nach Mexico zurückzureisen, von wo der Ileimweg angetreten wurde.

I) Ausbeute dieser zweiten Reise ist bedentend umfangreicher als die der ersten. Ausser 130 Kisten mit archäologischen und ethnologischen Materialien, welche zur llälfte dem Berliner Museum für Völkerkunde. zur Hilfte dem American Museum of natural history in New Y ork zufielen, wurdcn noch ïber 2't00 Pllanzen gesammelt, zum Teil in melıeren Exemplaren. Auch diese Sammlung ist im wesentlichen rorzïglich konservient und nicht nur an Vmang, sondern auch durch genane Angahen über Standorte, Verwendung etc. noch wertvoller als die der ersten Reise und bildet sowohl durch die beträchtliche Anzahl neuer Arten, als auch durch die Wiederanffindung mancher bisher erst ein oder wenige Dal gesammelter Arten rine wichtige Bereicherung des kgl. Ilerbars zu 
Berlin, dem laut Vertrag die erste Sammlung geschenkweise überwiesen wurde, während die ersten Dubletten Dr. Seler für sich, die zweiten für das Ilerbar zu New Y ork bestimmt hatte.

Im Folgenden soll nun ein Verzeichnis der Arten der zweiten Reise gegeben werden. Es wurden dabei auch noch die wenigen Familien der ersten Reise. soweit ihre Bearbeitung noch unerledigt geblieben war, hinzugenommen. Es sei hierbei bemerkt, dass die Nummern unter 1000 der ersten, die übrigen der zweiten Reise entstammen.

Bei der Bestimmung sellsst hatte ich mich der Mithülfe folgender Ilerren zu erfreuen: C. B. Clarke (Cyperaceen), A. Engler (Araceen), R. Schlechter (Orchidaceen), C. de Candolle (Piperaceen), 0. von Seemen (Salicuceen, Betulaceen, Fagaceen), G. Lindau (Polygonaceen, Acanthaceeu), II. Harms (Leguminosæ, Meliaceæ, Pussifloraceæ, Aralia(eie), J. Urban (Turneracex), E. Gilg (Loasacex), E. Koehne (Lythra(ex), J. Donn. Smith (Gesneracex), P. Graebner (Caprifoliaceæ). Es ist mir eine angenehme Pflicht, allen diesen Herren für ilıre Mitarbeit, ebens? wie Herrn Dr. Seler sellsst, der so fremndlich war, das Ilanuscript bezïglich der Rerhtschreibung der Ortsnamen durchzusehen, meinen rerbindlichsten Dank auszusprechen. Die Familien, bei denen nichts angegeben ist, wurden von mir selbst bestimmt.

CYPERACE.E II det. C. B. Clarke.

Pycreus helvus Liebm. sub Cypero.

Hab. in Mex., in prov. Chiapas in alveo rivi al Tonalà : Sel. n. 201't. Flor. : Febr.

P. piceus Liebm. sub Cypero.

Hab. in Mex., in prov. Mechoacan ad Pátzcuaro : Sel. n. 1223. - Flor.: Oet. Cyperus amabilis Vahl.

Hab. in Guatemala, in dept. Ifuehuetenango, ad Malacatan : Sel. n. 3282 et 3283. - Flor.: Sept.

C. Luzule Retz.

Hab. in Guatemala, in dept. Azabal in valle "Rio Hotagua " ad Los Amates : Sel. n. 335̈7. - Flor.: Jan.

C. scaberrimus Nees (=C. Buckleyi Britton).

Hab. in Guatemala, in dept. Huehuetenango, in distr. Nenton, in Llano ad Uaxackanal : Sel. n. 2710. - Flor. : Aur.

C. seslerioides $\mathrm{H}$. B. $\mathrm{K}$.

Hab. in Guatemala, in dept. Iluehuetenango, in pratis humidis ad Jacaltenango in $1610 \mathrm{~m}$. altitud.: Sel.: n. 2932. - Flor.: Jun. 


\section{Surinamensis Roxh.}

Hal, in Yevico, in prov. (baxaca all rivulos, in silva montana supra San Carlıs Yanlatepec, in prov. Cliapas in alveo rivi ad Tonali, et in finatemala in dept. lzalbal in valle "Rio . Motagna " all Los Amates: Sel. n. 1760, I $8 \times 8,333 ; 6$. Filır.: Jati. et Fels.

M"riscus alpinus Lielım. sub. Cypero.

IIah. in Guatemala, in dept. Izalbal in valle "Rio Ilotagua " ad Lios Amates: tiel. I1. 3338. - Flor. : Jan.

H. fabelliformis II. B. K. (= Cyperus Caracanus Liebm.)

Ilal. in (inatenala, in dept. Escuintla ad San Andres (Isuna et in dept. Iluelunteningu aul Jacaltenango : Sel. n. 2:378 et 2860. - Flor. : Maj.

H. Mulisii II. B. K.

Hah. in Ginatemala, in dept. IInehuetenango, in distr. Yenton all Cha“ula: Siel. II. 286 ;'.

hyllinga pumila Vichix.

Ilab. in Vex., in prov. Chiapas, in alveo rivi ad Tonala, et in Guatemala, in dept. Escuintla ad rivuli ripan ap̧ud San Andres Osuna : Sel. n. 1887 et 2:566. Flor. : Felsr.-llaj.

h. odoraln Vahl.

Hab, in (inatemala, in dept. Escuintla inter lapides in Finca Los Diamantes: sil. 11. 2':51. - Flor. : Nov.

II. leochar is geniculata R. Br.

Vulg.: " camalote ».

Ilab. in Guatemala, in dept. Alta Vera Paz, in fossis ad Petet apud. Cohan : Siel. I. 2't)3. - Flor: Dec.

II. ochreata Nees.

Ilah, in Mex, in prov. Chiapas in stagnosis al Comitan: Sel. n. 2773. Flur.: Ang.

Fimbristylis monostachya Hassh, forma spiculis tuabus subrara.

Hah. in Guatemala, in dept. Huehuetenango, in collibus siccis in $1600 \mathrm{~m}$. altitul. ad Claculà : Sel. n. 296' - Flor. : Jun.

Bullostylis capilluris Kunth.

IIah. in Guatemala, in dept. Hnehuetenango, in distr. Neuton, in unontibus (alcareis iuxta Uaxackanal: Sel. n. 3097, - Flor.: Jul.

1). Funckii Stemd. sul. Isolepide (= Scirpus helerocarpus S. Watson).

IIah. in Guatenala, in dept. Iluehuetenango ar. Malacatan : Sel. n. 32x't. Flur.: Sipt.

\section{J1, chomenu ciliatn Vahl.}

IIat), in Guatruala, in dept. Iluehuelenango in pineto supra tenton in 1200-I'100 แa. altitul. : Sel. 11. 2899. - Flor.: Jun.

1. redicuns Chans. ot siblechtel.

Ilah. in Cinatemalat, in dept. Izahal in valle "Rio. Motagua " apud los Amates: S..1. n. 33:3ï. - Flur. Jau. 
Ryuchospora aristata Boeck. (= Calypstrostylis Schiedeana Liebm.)

Hals, in Guatemala, in dept. Hnehuetenango, in distr. Nenton, inter plantas, in campis anno præcedente Zea plantata obtectis propullulantes in regione monlana humida apud Yalanbohoch et in silvis umbrosis ad Trinidad: Sel. 11. 2722,3076 . - Flor. : Aug.

R. cyperoides Mart.

Hab. in Mex., in prov. Chiapas in pratis apud Comitan : Sel. n. 3077. Flor.: Ang.

R. polyphylla Vahl.

Hab. in Guatemala, in dept. Ifueluuetenango, in distr. Nenton, ad Yalamboloch in silva primæva : Sel. n. 30't' - Flor. : Aug.

R. velutina Boeck. var. semihirsuta (Boeck.) C. B. Clarke.

Hab. in Cuatemala, in dept. Alta Vera Paz, in fossis ad Petet apud Coban: Sel. n. 2't01. - Flor.: Ilec.

Scleria bracteata Cav.

Hab. in Mex., in prov. Chiapas, in distr. Chilon, in clivis ad san Martin: Se 1. 11. 2280. - Flor. : Mart.

Uncinia Jamaicensis Pers.

Hab. in Guatemala, in dept. Chimaltenango, in umbrosis atque humidis cupressetis in Sierra Santa Elena apud Tecpam Guatem. in $3000 \mathrm{~m}$. altitnd.: Sel. n. 23วัว̈. - Flor.: Sept.

Carex cladostachya Wahllog.

Hab. in Mexico, in prov. Chiapas, in distr. Comitan in silvis umlorosis ad Sacchaná. et in Guatemala, in dept. Iluehuetenango ad Chacula : Sel. 1. 304ä et 3221 . - Flor. : Any.

C. Halleriana Asso.

Hab. in Guatemala, in dept. Huehuetenango, in distr. Nenton, in silvis et collibus calcareis ad Chaculá in $1600 \mathrm{~m}$. altitud. : Sel. n. $28 \% 5$ et $312 \%$. - Flor. : Jun. et Ang.

ARACE.E, det. A. Engler.

Authurium Seleri Engl. in Bot. Jahrb. XXV 1898, p. 4509.

Habit. in Guatemala, in dept. Huehuetenango in silvaticis supra parietinas calcareas iuxta Chaculá: Sel. n. 2643, - Flor. : Apr.

Dieffenbachia Oerstedii Schott, Engl. in Bot. Jahrbüch. XXVI, p. כ̋ว̈6.

Iab. in Guatemala, in dept. Escuintla in valle Cucunya iuxta San Andres Osuna : Sel. n. 2389. - Flor. carn. : Maj.

ORCHIDACE.E, det. R. Schlechter.

Platanthera sparsiflora Schltr. (= Habenaria sparsiflora Watson).

Hab. in Guatemala, in prov. Chimaltenango, in apertis cupressetorum prope 
Tinpan (iuatemala in "Sierra S. Elena " : Sel. n. 229's; in prov. Quezaltesnamo, in silvis nontium inter Totonicapan el Los Encuentros : Sel. n. 229:̈. - Fl. virill. : Septe.

\section{Hahenaria clypeata L,Il.}

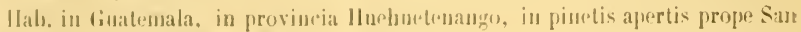
Aulres: šel. II. 3226. - sept.

II. diflusa A. Rich. et Cial.

Ilal,. in Guatemala, in proviucia Ilumbueteuango, in frulicetis prope San Andres : Sel. 2736. - Fl. virill. : Sept.

\section{II. maculose lill.}

Hlal, in Cinatemala, in provincia Alta Vera Paz, in graniumsis, ad Petet proju* Colian: sel. 11. 3408. - Fl. alb. : Dec.

\section{II. filifere Wats.}

Ialitat in Guatemala, in provincia IIuehuetenango, in lumidis prope Cuesta de la Concepeion : Sel. n. 2739. - Fl. virid. : Sept.

Xilıe mit der chilenischen 1 . maxillaris LAll. verwand, von ihr jedoch durch die bedeutend läugeren vorderen Segmente der Sepalen, das Labellum und den wenizrer stumpfen Sporn unterschieden; anch hahitnell durch gleichuässiqere Belaulunug zu erkennen. Sollte nicht Reichenbachs II. maxillaris in Beitr. Orch. ('entr. Amer. hierher gehören? Das plötzliche Auftreten einer rein chilouischen Art in Central-Amerika scheint mir sehr zweifellaft.

II. Selerorum Schltr. 11. sp. Gracilis erecta vel adscendens, c. '40 ('m. alta; caule tereti, subflexuoso, pennæ anserinæ crassitudine, foliato, glaberrimo; foliis erecto-patentibus oblongis rel oblongo-ellipticis, gliberrimis, reticulato-renosis, basi vaginantibus usque ad $7 \mathrm{~cm}$. longis, ad apicem caulis versus sensim decrescentibus; racemo oblongo vel cylindrico laxe purifloro; bracteis oratis acutis vel acuminatis ovario graciliter pedicellato multo brevioribus; floribus viridi-flavescentibus illis $I I$. alat $\mathrm{Hl}$. fere arfuimagnis; sepalo interınedio suborbiculari obtuso, 0.6 cı. dianı.. cucullato. sepalis lateralibus deflexis obliquis late oblongis apice breviter acuminatis $0.6 \mathrm{~cm}$. longis, medio fere $0,4 \mathrm{~cm}$. latis; petalis erectis oblongis apice truncato-obtusissimis, carnosulis, basi haud dentatis, 0 , ö cm. longis. medio fere $0.2 \mathrm{~cm}$. latis; labello deflexo, lineari obuso, basi interdum uringue denticulo minuto donato, $0.8 \mathrm{~cm}$. longo, vix $0.2 \mathrm{~cm}$. lato, carnosulo, calcare filiformi acuto dependente, ovarium bene excedente, c. 3 cm. longo; anthera emarginata, canalibus gracilibus adscendentibus; rostello humili, lobo intermedio triangulari obtusiusculo carnoso; processilums stigmaticis crassis, clavatis, canilibus antherarmm duplo brevioribus, apicr colırentilus; capsula clavata, glabra, pedicellata.

Habitat in Ciuatemala. in provincia Alta Vera P'at, al maryines silvarum prope Colan: Sel. n. 2992. - Dec. 
Diese Novität gehört in die Grupve der Otontopetalce und zwar in die Näle der H. clcta Hk. Sie weicht von dieser in vielen Charakteren ab, so im IIabitus, dem gestielten Ovarium unı dem langen fadenförmigen Sporn.

II. vaginala A. Rich.

Hahitat in Nexico: In provincia Chiapas, in pratis humidis prope Comitan : Sel. n. 30 '1. - Fl. virid. : Aus.

Spiranthes anrantiucu Hemsley.

Habitat in Nexico, in provincia Chiapas, in pratis humidis prope lagtamam Tepancuapam : Sel. n. 2311 . - Fl. aurant. : Aug.

S. cinnabarina IIemsley.

Habitat in Guatemala, in provincia Huehuetenango, in graminosis lapidesisque prope Chacula, alt. e. 1600 uı. : Sel. n. 2398 ; in collibus calcareis iuxta Caxackanal : Sel. n. 2396, 2399, 2386. - Flor. aurant. : Jul.-Aug.

S. ochracea A. Rich. et Gal.

Habitat in Guatemala, in provincia Inehuetenango, in umbrosis quercetorum iuxta Uaxachanal solo argillaceo: Se l. n. 3068. - Flor. alhid. viridi-venos. : Jul.

Verglichen mit dem Original in Paris durch Herrn Finet. Nicht im Ilemsl.Biologg. erwähnt.

Craniches Schaffneri Rehb. f.

Habitat in Nexico, in provincia Nechoacan, in fruticetis humiclis inter Selaginellas supra "Wonte Calvario» prope Patzcuaro: Sel. n. 1283. - Flor. virid. : Nov.

\section{C. thysanochila Rob. et Greenm.}

llabitat in Mexico, in provincia Oaxaca, in umbrosis pinetorum quercetorumque prope Canada Sta. Maria in solo calcareo: Sel. n. 1't09. - Flor. nivei : Dee.

Ponthieva glamdulosa R. Br.

Habitat in Guatemala, in provincia Salama, in silvis montium al Cuesta de Choacuz : Sel. n. 21't'. - Flor. allid. : Dee.

P. Guatemalensis Rchb. f.?

Habitat in Guatemala, in provincia Huehuetenango, in clivis montium supra Tod. los Santos: Sel. n. 27366. - Flor. albil. : Sept.

Microslylis longisepala Ridl.

Habitat in Guatemala, in provincia Huehuetenango, in graminosis silvarum lumirlarum pr. Pocobastic : Sel. n. 3030. - Flor. virid. : Aug.

II. minutiflora Schltr. n. sp. Erecta, habitu .I. monophyllos Ldl., $15020 \mathrm{~cm}$. alta, herbacea ; caule stricto, medio unifolialo, tereti, glaberrimo, basi vagina brevi excisa (an semper?) donato, c. $0,3 \mathrm{~cm}$. crassitudinis; folio erecto vel suberecto lanceolato-oblongo obtusiusculo, basi vaginante, $7-8 \mathrm{~cm}$. longo, medio fere vix $2 \mathrm{~cm}$. lato; spica subdense multillora cylindrica, folium excedente; bracleis minutis deltoideis, erecto-patentibus, pedicello florum multo brevioribus; floribus graciliter pedicellatis, in genere minimis, viridibus; sepalis aqualibus lineari-ligulatis obtusis, uninerviis, $0,1 \mathrm{~cm}$. longis; petalis-linearibus obtusiusculis, sepalis paullo brevioribus; lalello 
concavulo ereclo, deltojdeo acuto vel leviter acumiuato, basi auriculato hastato, $0,1 \mathrm{~cm}$. Iongo, basi intus callis 2 minutis rotundatis ornato; columna brevi; anthera obtusa; ovario gracililer pedicellato clavato, glaberrimo.

Habitat in Ciuatemala, in provincia Ihuhnetenango, in planitie inter Todus los Santos et Chiantla, alt. 3000 m.: Sel. 11. 2337. - Flor. virid. : Sept.

lch schlaye vor, die eben beachriehene Pflanze neben.. . mrianchemifolia Relıl. $t$. aus Mexico unterzubringen. Die Geatalt des Labellums ist ähnlich, doch sind tie Blitter erheblich verschielen. ebenso die Sepalen und Petalen. Unter allen bisher bekannt geworilenen Arten lat $M$. minutiflora die kleinsten Blaten.

Slelis Guutemulensis Schltr. n. sp. Gracilis, caspitosa; caulibus gracili-

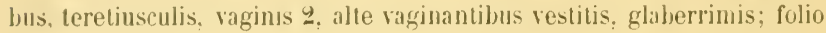
lanreolato-oblongo apice hreviter et obtuse bilobulato, basi sensim in petiolım angustato, coriaceo, petiolo incluso ti-9 cm. Jongo, medio fere I cu. lato; spicis gracilibus vulgo geminis laxe unultifloris. folium plus minus excedentibus, interdum paullo breviorioribus; bracteis cucullatis obtusis, ovario pedicellato itquilongis. glabris; floribus parvulis nutantibus Iuride virescentibus, bilabiatis; sepalo dorsali concavo oblongo obIıso, trinervio, glaberrimo, $0.2 \mathrm{~cm}$. longo, sepalis lateralilıus intermedio paullo brevioribus trinerviis in labium inferius late oblongum apice breviter excisum connatis; petalis minutis rhomboideis obtusangulis; labello orbiculari apice in apiculum brevem producto, concavo, intus. Iongiludinaliter lineis 2 incrassatis ornato, sepalis crassiore, petalis paullo majore: ovario cyliudrico, pedicello axquilongo.

Habitat in Guatemala. in provincia Inehuetenango, epiphytica in arburibus silve primave prope Yalambohoch : Sel. 11. 2316. - Ang.

In der Gruppe der Labiatce neben S. prarlipes Rchb. t. unterzubringen.

Pleurothallis sprec.

Ilabitat in Nlexico. in provincia Chiapas, epiphyliea in quercetis inter Bahuruc "t Yaxha: Sel. n. 26łö. - Flor. tlav.: Mart.

Sämtliclie Blitten des einzigen Exemplares sind in ilırer Entwicklun bereits zu weit vorgeschitten. Offenbar gehört die Pfianze zur Gruppe der "Elongatc»".

Physosiphon Loddigesii lall.

Ihabitat in Mexico, in provineia Chiajas, in yuercelis inter Babucue et Yaxha :

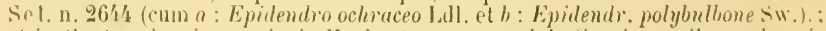
it in Guatemala. in provincia Iluehuetenango, epiphytica in rupibus ealeareis jrope Quen Santu : Sel. n. 2998̈. - Flor. aur. : Mart. el Jul.

Isochilus limeuris R. Br.

Ilabitat in tiuatemala. in provincia Iluehurenango, epiphytica in arborihus rupiluspue insta laxactanal: Sel. 11. 272'1. - Flor. ros.: Aug.

J. spec.

Ilabitat in Mexion, in provincia Chiapas, epiphntica in quercibus iuxta Hunhattil: Sel. II. 260 ' a. - Mart.

lixemplar oline Blinten. 
J. spec.

Habital in Yexico, in provincia Chiapas, una cum precelente : Sel. I1. 26016. - Mart.

Exemplare ohne Blüten.

Seraphyta diffusa Schltr. (= Epidendrum diffusum Sw., Seraphyta multiflura Fisch. et Ney.)

Habitat in Guatemala, in provincia Hueluetenango, in quereetis prope Chaculá, iuxta Uaxackanal, alt. 1400-1600 ped. : Sel. 11. 2320 11. 2321. - Flor. fusco-purpur : Aug.

Colia macrostachya I.dI.

Habitat in Guatemala, in provincia IIuelıuetenango, in rupibus calcareis erosis prope Chaquial : Sel. 1. 234't. - Flor. ros. : Sept.

Arpophyllum alpinum Lill.

Habitat in Guatemala, in provincia Chimaltenango, in cupressetis montium "Sierra Sta. Elena » alt. c. 3000 m. : Sel. n. 2307 - - Fl, ros. : Sept.

A. gigantenm LdI.

Habitat in Guatemala, in provincia Escuintla, epiphytica in arboribus silvarum primævarum prope Finca Java: Sel. n. 2'׳ö.. - Nov.

Hartwegia purpurea Ldl.

Habitat in Guatemala, in provincia Chimaltenango, in quercetis prope Poaquil: Sel. n. 2623. - Fl. liete ros. : Apr.

Epidendrum atropurpureum Willd.

Halsitat in Jexico, in provincia Chiapas, epiphyticum in arhoribus rupihısque prope Cerro de Tonala: Sel. n. 1803. - Fl. brunn., labello purpureo : Febr.

E. aurantiacum Batem.

Habitat in Guatemala, in provincia Chiquimula, in pinetis et in rupibus supra

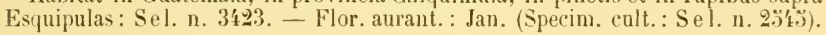

E. ciliare L.

Habitat in Guatemala, in provincia Huehuetenango, in arboribus prope Quen Santo, alt. 1300 m. - Sel. n. 23Iวั. - Flor. niv. : Aug.

E. cochleare L.

Habitat in Guatenala, in provincia Huehuetenango, in quercibus prope Chacula : Sel.Q306; in arboribus prope Quen Santo : Sel. 11.2328 u. 3002. - Jul.-Sept.

E. erubescens LdI. Nov.

Hahitat in Jexico, in provincia Oaxaca, in Cerro San Felipe : Sel. n. 1401. -

E. glumaceum ldd. var?

Habitat in Guatemala, in provincia Huehuetenango, in quercibus prope Chacula : Sel. 11. 2:327. - Aug.

Es ist wahrscheinlich, dass diese Pflanze als neue Art zu betrachten sein wird; leider ist das Material zu spärlich un hier diese Frage endgültig zu entscheiden

E. ochraceum Ldl.

Habitat in Guatemala, in provincia Huehuetenango, in rupilsus prope Quen Santo, alt. $1300 \mathrm{~m}$. : S el. n. $299 \mathrm{I}$; et in prov. Chimaltenango in quercibus prope Poaquil : Sel. n. 239't. - Fl. flavid. : Apr. et Jul. 
E. papyrifermu Schltr. n. sp. Gracilis, decumbens, pseudohnlbis angustis subcylindricis, lasin versus flaullo dilatatis, vaginis papyraceis arcte amjlectentibus restitis, $0-7 \mathrm{~cm}$. longis supra basin $0, \mathbf{Z} \mathrm{cm}$. diam. $\underline{-}$ - (rel rarius :3-) foliatis ; foliis limearibus obtusis. a pice breviter ac obtuse bilobulatis, 1:3-17 cm. lougis, medio fere 1-1,2 cm. latis; pedunculu terminali gracili. folia panlo excedente, basi vagina arcte amplectente restito. medio sfpuamellis $2-3$ ininutis deltoideis acumiuatis ornato; racemo laxe plurifloro, folia excedente; bracteis minutis deltoideis wario pedicellato multoties brevioribus; floribus erecto-patentibus. flavidis brunueo-junctatis " (file. collectoris) c. 1.j cm. dan., crassioribus; sepalis oblongo-ligulatis basin versus paullo angustalis, apice oblusis. trinerviis, 1.2 cm. Jongis, infra apicen $0.3 \mathrm{~cm}$. latis; petalis erecto-patentibus oblougis obtusis vel breviter apiculatis trinerviis, sepalis valde similibus, vix minoribus, labello columna basi tantum adnato, trilobo, medio callo aureo apice trilobulato longitudinali ornato, 1.9-1,3 cm. longo, lobis lateralibus oblongis valde obtusis, Jolo intermedio oblongo truncato-oblusissimo, laterales excedente, margine undulato-crispato, labello medio apice Joborum Jateralium $1.2 \mathrm{~cm}$. lato (explanato); columna semitereti; $0,1 \mathrm{~cm}$. Ionga, clinandrio, trilobo. lobis alte laceratis; authera subglobosil obtusissima polliniis ovoideis compressis; ovario pedicellato clavato glaberrimo.

Habital in Mexico, in provincia ('hiapas, in quercetis inter Bahucuc et Yaxha: sicl. 11. 2603. - Nart.

In der Sektion Encyclium zur Gruppe der "Sarcochilu» zu bringen, daselbst mit I: oclirrceum Ldl. verwandt. Durch bedeutend grïssere Blüten und durch das Labellum ausgezeichnet.

\section{E. polyanthrm Lill.}

Ilabitat in Cinatemala, in provincia Huehnetenango. epiphyticum in arhoribus rupihusyne prope Quen Santo: SeI. 11. 231't. - Fl. llavid.: Jul.

\section{E. radiutum LAll.}

Hahitat in Guatemala, in provincia Ilueluuetenango, in quercetis inter Gialchanal et Cian-quintic, alt $1300 \mathrm{~m}$. : Sel. n. 2312. - Flor. flavesc. : Jul.

\section{E. radicans Pav.}

Ilabitat in .Hexico, in provincia Cliapas, in silvis montium inter ()xcluce et Sul Martin : Sel. 1.9800 et in Guatenala, in provincia Escuintla, in fruticetis saxusispue in rivulis vulcani "del Fuego " prope Asuncion : Sel. n. ýt6t. Plur. aurantiac. : Nov.

\section{E. геrrucosum Siw. (nec. L.ll.)}

Habilat in Hexieo, in provincia Chiapas, in montibus inter Oxchuc et san Martin: Sel. 11. 2619. - Fl. albicl. : Mart.

seirucyllium Giemma Rehb. f.

Ilabitat in (iuatemalit, in provincia Iluelunetenango, in rupibus ealeareis jrope (uen Santo: Sel. n. 2817 . - Fl. ros.: Jul. 
Laclia autumnalis Ldl.

Habitat in Hexico, in provincia Oaxaca, in Cerro de San Felipe: ScI. n. 1100. - Nov.

Sobralia decora Batem.

Habitat in Guatemala, in convalle umbrosa juxta thumen "Rio de Vacas", ad Salida de Izabal : Sel. n. 2996 . - FI. roseis : Oct.

\section{s. macrantha Ldl.}

Iabitat in Guatemala, in provincia Huehuetenango, in truncis arbormu in quercetis prope Chacula, alt. c. $1600 \mathrm{~m}$. : Se I. n. 2397. - Flor. ros. : Aug.

Bletia campanulata Lalav, et Lex.

Habitat in Mexico, in provincia Vichoacan, in fruticetis clivorun supra Monte Calvario prope Pátzcuaro : Sel. n. I2I6. - Fl. violaceo-purp. : Nov.

B. Parkinsonii Hook.

Habitat in Mexico, in provincia Oaxaca, in clivis lapidosis calcareis prope San Miguel Achiutla: Se I. n. I46I. - Fl. pallide violac. : Dee.

B. verecunda $\mathrm{R}$. Br.

Habitat in Mexico, in provincia Chiapas, in silvis montium juxta viam ad Cinacautan: Sel. n. 2268, in monte Cerro de Tonala: Sel. 11. 184\%. in clivis montium inter Oxchue et San Martin : Sel. n. 2200. - Fl. ros. vel violac. : Febr.-Mart.

Govenia deliciosa Rehb. f.

Halsitat in Guatemala, in provincia IIuehuetenango, in fruticetis hmmidis prope Yalambohoch: Se1. n. 2323. - Flor. flavesc.: Aug.

Maxillaria vel Ornithidium sspp.

1. Habitat in Mexico, in provincia Chiapas, in quercibus juxta Hunkanal : Sel. 1. 23I9. - Fl. brumn. : Mart.

Leider ist das Exemplar ohne Blüten.

II. Ilabitat in Mexico, in provincia Chiapas, in quercibus inter Baliueuc tt Yaxha : Sel. n. 2646. - Fl. flav. : Mart.

Ebenfalls oline Blüten.

Oncidium ornithorrhynchium H. B. Kth.

Habitat in Guatemala, in provincia Escuintla, in arboribus silvarum primævarun prope Finca-Java : Sel. n. 2453. - Fl. pallide ros. : Nov.

O. reflexum Ldl.

Habitat in Guatemala, in provincia Escuintla, in arboribus silvarum prinævarum prope Finca-Java: Sel. n. 245\%4. - Fl. aur. brunneo-macul. : Nov.

Odontoglossum bictoniense Ldl.

Habitat in Guatemala, in provincia Huehuetenango, terrestris in silvis prope Cuesta de la Concepcion: Sel. 11. 2326. - Sept.

Orchidacearum species indeterminabilis.

Habitat in Guatemala, in provincia Huehuetenango, in truncis arborum in silvis primævis prope Yalambohoch: Sel. n. 2305̆. - Aug.

Die Pflanze gehört vielleicht zu den Gongorince, kann aber nicht bestimmt werden, da die Blüten gänzlich verdorben sind. 
PIPERACEA det. Cas, de Candolle.

Piper anyustifolium R. et l'av.

Vule.: "Cordoncillo".

Ilab. in Mex., in prov. Hidalgro prope Iluejulla: Se l. I. 8\$7. - Flor. Apr.

P. subpellatum Willd.

Hab. in Guatemala, in dept. Izabal in valle lio Motagua in palmeti margine ad Los Amates: Sel. n. 3327. - Flor. : Jan.

P. tuberculalum Jacq.

Vulg.: "Cordoncillo".

llab. in Mex., in prov. Chiapas ad ripam fluvii ad Tonalá: Sel. 11. 1872. Flor.: Felor.

P. unguiculatum R. et Pav.

Vulg. : "Cordoncillo", "yè-dána ".

Hab. in Mex., in prov. Oaxaca, in distr. Tehuantepec ad Huilotepec: Sel. 1. 1776. - Flor.: Jan. - Wird wegen seines Wohlgeruchs zur Behränzung der Heiligenbilder verwandt.

Peperomia galioides Kunth.

Hal., in Mex., in prov. Mechoacan in muris ad Tzintzuntzan: Se l. n. 1329.Flor.: Oct.

P. hispidula A. Diet.

Hab. in Guatemala, in dept. Hutehuetenango, in distr. Jacaltenango ad Toulos los Santos inter murorum lapides: Sel. 11. 2740. - Flor. : Sept.

$P$. pellucida Kunth.

Hab. in Guatemala, in dept. Huehuetenango inter Todos los Santus et Chiantla in cordillera: Sel. n. 31/'4. - Flor. : Sept. - Det. John Donn. Snith.

P. reflexa A. Dietr.

Ilab. in Mex., in prov. Chiapas, in distr. Comitan, in arborilus ad Hunhanal: SeI. и. 2:'sī. - Flor. : Mart.

1'. umbilicala R. et Pav.

Hab. in Guatemala, in dept. Iluehuetenango inter Todos los Santos el Chiantla in cordillera clivo in saxis et in distr. Malacatan in Estancia de la Virgen in arborum pelle: Sel. n. 2731 et 2743 . - Flor. : Sept.

S.ILICACE.E, det. O. von Seemen.

Salix taxifolia kunth.

Ilab. in Mex., in prov. Oaxaca in distr. Yauhtepec in valle fluvii a Tehumtepec » infra Totolapan: Sel. 11. 17:35. - Flor. et fruct. : Jan.

BULL. НЕнв. воLss., juillet 1899. 
BETULACE.E, det. (). vo n Seemen.

Aluus Jorullensis H. B. K. var. castanifolia Reg.

Hal. in Mex., in prov. Oaxaca, ad rivulos prope Tlaxiaco et prope S. Martin: Sel. n. 14:59 et I' 170. - Flor. et fruct. : Dee.

FAGACE.E, det. O. von Seemen.

(unereus acutifolia Née var. angustifolia DC.

Vutg. : "encino de agua», "arbol de agua», "tnu-nyù (mixt. = "Baum des Landes $n)$.

Ifab. in Mex., in prov. Oaxaca in distr. Nochistlan in silva montosa supra Teconatlan: Sel. n. 1595.

(1. acutifolia Née var. Bonplandii DC:

Hab. in Mex., in prov. Oaxaca in distr. Nochistlan in silva montosa inter Cirauhtlilla et Quilitongo, et in distr. Chiapas in clivo Hacienda de Calvario: Sel. 1. I' 8 ' et 2072. - Flor.: Mart.; fruct. : Nov. - In Nochistlan "Bestand bildend mit encino blanco (=Q. oblongifolia Torr.) und Thuya ".

(Q. aculifolia Née var. lanceolata DC.

Hab, in Hex., in prov. Oaxaca, in distr. Cuicallan prope Salome: Sel. n. 63. - Fruet. : Jü.

Q. conspersa Benth.

Hab. in Mex., in prov. Oaxaca, in silva montana inter San Carlos et San Bartolo Yauhtepee: Se 1. 11. 1630.

Q. conspersa Benth. vel affinis.

Hah. in Mex., in prov. Chiapas, in distr. Comitan in pineto-querceto inter Bahucue el Yaxhá: Sel. 11. 22883. - Flor. et fol, novell. : Mart.

Q. Hartwegii Benth. vel affinis.

Hah. in Mex., in prov. Chiapas, in pineto inter distr. Tonala et Tuxtla Gutierrez ad Cuesta San Fermando: Se I. 11. 18533.

Quercus Mexicana H. et B. (= Q. crassipes H. et B.).

Hab. in Guatemala, in dept. Huehuetenango, in distr. Nenton in montiluus calcareis parce silvigeris ad Uaxachanal: Sel. 11. 2667. - Fruct. juven.: Aus. Q. oblongifolia Torr. vel affinis.

Vulg. : "chaparro", "encino blanco".

Hab. in Nex., in prov. Oaxaca, in distr. Nochistlan in Canada infra Cuauhtlilla, et in distr. Tlacolula in Canada supra Totolapam totos montium clivos cum Acaciis et Cereis obtegens, et in distr. Yauhtepec apud Agua escondida : Sel. n. $1483,1752,1757$.

U. polymorpha Cham. et Schlechtd.

Hah, in Guatemala, in dept. Huehuetenango, in distr. Nenton in collibus calcareis in 1300-1400 m. altitud. ad Uaxachanal, silvas formans cun Thuyis, Acaciis, Ficis, aliisque : Sel. n. 3067. - Fruct. juven. : Aug. 
(.) reticulata $\mathrm{HI}$, et B.

Vulg.: "chaparro", "tnu-yaha” (mixt. = "gemeir.er Baum»?).

Hab. in Nex.. in prov. (laxaca, in distr. Nochistlan in silva nontana inter Cuauthlilla et Quilitongo et supra Treomatlan, silvas formans cum aliis quercumm speciebus et cum Thuvis: Sel. n. I'82 et 1593. - Flor. et fol. novell. : Jee

(). reticulnata II. et B. var. Segoviensis $\mathrm{Wg}_{\mathrm{g}}$.

Vulg. "encino amarillon, “ tnu-yáa ».

Ilab. in Mex., in prov. Oaxaca in distr. Nochistlan in silvis montanis supra Tecomallan et supra San Carlos Yanhtepec et in prov. Chiapas in distr. Comitan una cum pinis supra Saconeja: Sel. 11. 189\%, 1761, 2386. - Flor. et fol. novell. : Mart.

(1. reticulata I1. et B. vel affinis.

Vulg. : aencino amarillon.

Ilab. in Mex., in prov. Oaxaca, in distr. Nochistlan ad Cuauhtlilla ef in silva montana inter San Carlos et San Bartolo Yauhtejec: Sel. n. 1:87 et 1631.

Q. tomentosa Willd.

Hab, in Hex, in prov. Oaxaca, in distr. Cuicatlan prope Salorne, et in liuatemala in rlept. Ifuehuetenango, in distr. Nenton in montibus calcareis parce silvigeris ad Uaxackanal: Sel. n. 62 et 2668. - Fruct. : Jun. et Aug.

\section{MORACEL.}

\section{Dorstenia contrajerva L.}

Hals. in Guatemala, in dept. Escuintla in locis lsumidis umbrosis in valle Cucunya apud Los Diamantes et in dept. Alta Vera Paz ad Coban : Sel. n. 23ly et 3411. - Flor. : Maj. et Dec.

POLYGONACE.E II., det. G. I.indau.

Eriogonum annum Nutt.

Hab. in Texas ad Cotulla: Sel. n. 1020, - Flor. : Oet.

Polygonum spec. forsan nova.

Hab. in Guatemala in dept. Ifuchuetenango in Cnesta de la Concepcion sub fruticibus: Sel. n. 3213̈. - Flor. : Sept.

Coccoloba spec, affinis $C$. Schiedeanc Jind., verosimiliter nova.

IIah. in Hexico, in prov. Oaxaca in ripa fluvii Arroyo ad S. Carlos Yauhtepec: Sel. 13. I612. - Fruct. : Jan.; floril). mancis.

C. Liebmamnii Liıdan.

Hah. in Hexico, in prov. Oaxaca in collibns aridis ad Tequisistlan: Sel. I. 1719. - Flor. : Jan.

Triplaris anviculatn Meissn.

Hab, in Hexico in prov. Chiapas in silva inter Tapána et La Junta in distr. Tonala: Sel. n, 2010 . - Fruet. : Febr. 
Podopterus mexicanus H. B. K.

Ilab. in Mexico in prov. Oaxaca in collibus aridis ad Terguisistlan et in prov. Colima ad Manzanillo: S el. n. 1718 et 3ł'․ - Fruet. : Jan.-Hart.

\section{MENISPERMACE.E II.}

Cocculus oblongifolius DC. forma angustifolia Eichl.

Hab. in Mex., in prov. Nuevo Leon al Monterey et in prov. Oaxaca in distr. Tehuantepec at Huilotepec: Sel. n. 10'8 et 1778. - Flor.: Jan; fruct.: Oet.

Cissampellos Pareira Lan.

Hab. in Mexico in prov. Chiapas in distr. Tuxtla Gutierrez ad Ocozuquauhtla et in Guatemala in distr. Escuintla ad San Andres Osuna et in dept. Zacapa in valle ad Tutumajio apud S. Agustin Acasaguastan: Sel. n. 19'7, 2372, 3303. Flor.: Febr.-Ilaj.; fruct. : Dec.

C. Pareira Lam. forma intlorescentiarum bracteis minoribus recedens.

Hab. in Guatemala in dept. Huehuetenango in distr. Nenton in via publica in Quen Santo: Sel. n. 2936. - Flor. Jul.

\section{MORINGACEE.}

Moringa oleifera Lam.

Hab. in Guatemala in dept. Zacapa ad Santa Hadalena Acasaguastan in collibu: aridis et in Mexico in Colima culta: Sel. n. 3300 et 3128. - Flor. in Guat.: Dec. ; in Mex. : Apr.

\section{LEGUMINOS.E HII., det. H. Harms.}

I. C.ESALPINIOIDE.E.

Banhinia amblyophylla Harms n. sp. (Sect. Casparia); frutex ramulis molliter pubescentibus, demum glabrescentibus; foliis peliolatis (petiolo velutino-pubescente), ambitu suborbicularibus, basi leviter cordatis vel truncatis, supra puberulis, subglabrescentibus, subtus dense tomentellis, foliolis ultra medium vel alte (ad $\%$ vel ultra $\%$ ongitudinis) connatis, rotundatis, 4-nerviis vel 3-nerviis; racemis multifloris pubescentibus; calycis limbo spathaceo, extus pubescente; petalis 5, unguiculatis, lamina lanceolata; stamine fertili unico, filamento elongato, ceteris filamentis in tubum intus apertum connatis.

Blattstiel etwa $2 \mathrm{~cm}$. lang. Blättchen $4, \ddot{y}-7,30 \mathrm{~cm}$. lang, $2.50-4 \mathrm{~cm}$. breit, über die Mitte, bisweilen fast bis zur Spitze verwachsen (sodass das ganze Blatt oben nur schwach ausgerandet ist), oben gerundet. Bezüglich der Blüthen stimmi die 
Art fast ganz mil der weit verbreiteten und sehr variabehn $B$. divaricalu $\mathrm{l}$. iiberein. Viclleicht ist die neue Art iiberhaupt eher als Varielät dieser anzusehen; atufïllig sind jedenfalls die nicht spitzen oder nur stumpfen, sondern abgerunde. iell. selır weit hinauf rerwachsenen, relativ stark belıarten Blätlelien. Die Blüthen sind uach Seler weiss.

Ilabitat in Mexico, in prov. Uaxaca, in distr. Tehuantepec in ralle silvatica inter Tequisistlan el Jalapa et in distr. Juchitan in silva planitiei all Tapana: S.i. I. 1689 et 1890 . - Flor. : Jall.-F, br.

\section{B. dixaricata $\mathrm{L}$.}

Ilalı. in Mex., in prov. Oaxaca, in collihns siccis silvigeris ad San Bartolo Yaulitepec et in prov. Chiapas in distr. Tuxlla Gutierrez ad Hac. Petapa: Sel. n. 169 ' et [9's). - Flor.: Jan. et Febr.

\section{B. Lunaria Cav.}

Hab. in Hex., in prov. Oaxaca in distr. Telıuantepec in valle silvatica inter Tequisistlan et Jalapa: Sel. I1. 1687. - Flor. : Jau.

B. Seleriana Harms. n. sp. (Sect. Pauletia); arbor ramulis dense ferrugineo-tomentosis rel velutinis, demun glabris; foliis petiolatis, petiolo relutino; lamina suborbiculari-ovata rel suborbiculari, basi leviter cordatil vel emarginata, ad 1/1 - $1 / 2$ Iongitud inis bilobata (lobis rotundatis vel obtusis, rarius subacutis), 9-11-nervia, supra glabra, subtus molliter Lomenlella; racemis foliis oppositis, satis elongatis, purifloris rel $\mathrm{m} u \mathrm{ltifl}$ ris, tomentello-velutinis ; floribus pedicellatis, bracteis linearibus, lrevibus; alabastris ac uminatis; receptaculo brevissimo, calycis limbo spathaceo, demum reflexo, acuminato, apice denticulato, extus velulino-puberulo; petalis 5, breviter unguiculatis, oblanceolatis rel oblongo-oblanceolatis, in unguem angustatis, obtusis vel subacutis, glabris vel subglabris; staminibus 10 , alternis brevioribus et longioribus, filamentis glalıris, basi in coronula quadam marginem receptaculi cingente pilosiuscula coherentibus; ovario lineari, pubescente.

Nach Seler hohe Bäume mit weissen Blüthen. Blattstiel 10-20 mm lang. Blïtter

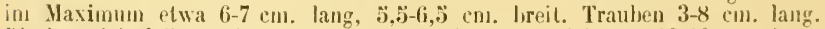

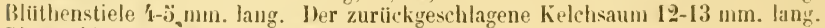
Blumenbläter $11-13 \mathrm{~mm}$. lang.

Halnitat in Guatemala in dept. Huehuetenango, ad Quen Santo in clivis et collilus apricis calcareis, in circ. 1100 u. altitud.: Sel. n. 2797 et 3031 . Flor. : Jul, et Aug.

Diese Art dìrfte der mir unbekannten B. A nulvieuxii Hemsley in Biolog. CentraliAmeric. 1, 336 nahe kommen, die jeloch nur $3-4$ blütige Trauben und kleinere Blälter (8 lines long) besitzen soll.

Cassia Cacilix Harms n. sp.; frutex ramis pubescentibus sel puberulis. demum glabrescentibus; foliis petiolatis 7-9-jugis, elongatis, petiolo communi puberulo, inter pleraque paria foliolorum glandulis instructo. 
foliolis brevissime petiolulatis, anguste ellipticis vel oblongis, basi rotundatis, apice obtusis, membranaceis, glabris, subtus ad nervum medium puberulis rel subglabris, subtus subglaucis; stipulis elongatis, subulatolinearibus, deciduis; racemis axillaribus, elongatis, longe pedunculatis, multifloris rel plurifloris, puberulis; bracteis lanceolatis vel ovatolanceolatis, subulatis, pedicellis brevioribus; calyce glabro, sepalis suborbicularibus, staminibus fertilibus $\overline{7}$, antheris brevissime obtuse rostratis; orario pubescente.

Blattspindel etwa 10ั-20 cm. lang; davon der Stiel 4-6 cm. lang. Blättchenstiele 2-4 mm. lang, Blättehen 3-ö cm. lang, 1,5̈-2,3 cm. breit, unterseits etwas grangrünlich. Nebenblätter etwa bis 1,7 cm. lang. Trauben (mit Stiel) $15022 \mathrm{~cm}$. lang, der Stiel etwa $8-10 \mathrm{~cm}$. lang. Blüthenstiele 10-15̆ $\mathrm{mm}$. lang. Kelch etwa ö-6 mm. Blïthen gelb.

Habitat in Guatemala, in dept. Huehuetenango, ad Todos los Santos, in fruticetis: Sel. n. 3172. - Flor.: Jun.

Da Früchte nicht bekannt sind, so ist die genaue Stellung der Art nicht mit Sicherheit anzugeben. Sie dürfte aber wohl am besten in die Gruppe Chamcesenna $\$$ Pachycarpo Bth. einzureihen sein, innerhalb deren sie sich unter anderem durch die relativ grossen Blätter auszeichnet.

\section{Chamecrista L.}

Vulg.: " wild coffee ".

Hab. in Texas al Galloway: Sel. n. 1009. - Flor. : Oct.

\section{C. fexuosa L.}

Vulg. : " tamarindillo ».

Hab. in Hex. in prov. Oaxaca, in distr. Juchitan inter Chicapa et Izhuatan ad lacus marginem : Sel. 11.1977 et 2027 . - Flor. et fruct. : Jan.

\section{C. glandulosa L.}

Hab. in Guatemala, in clivis siccis in Barranca del Rio de las Vacas, ad Salida de Izabal : Sel. n. 2286. - Flor. : Oct.

\section{C. hispidula Vahl.}

Hab. in Guatemala in dept. Huehuetenango in distr. Nenton in montibus calcareis inter Caxackanal et Quen Santo et in pineto supra Nenton in 1200-1300 m. altitud. : Sel. 11. 2662 et 29501 . - Flor. : Jun.

C. hispidula Vahl, forma sepalis glabris recedens.

Hab. in Mex., in prov. Chiapas in Cerro de Tonalä in pratis : Se l. n. I893. Fl. et fr. : Febr.

C. species affinis C. hispidulce Vahl.

$$
\text { Vulg. : " dormilona ". }
$$

Hab. in Mex., in prov. Oaxaca in distr. Juchitan inter Chicapa et lzhuatan in Llanos ad marginem lagunæ et ad Rancho Las Anonas: Sel. n. 1788 et 2024. Fl. : Jan, et Febr.

C. multiflore Mart. et Gal.

Hab. in Mex., in prov. Oaxaca ad Etla et ad Oaxaca in monte "Alban »: Se l. n. 1480 et 1741 . - Flor. : Nov, et Dec.; fruct. : Dec. 
C. occidentalis $\mathrm{L}$.

Hab. in Texas ad Longview Junction et in Guatemala oppido : Sel. $\mathbf{n} .1001$ et $220 \%$. - Fl. et fr. in Guatem. : Yaj: in Texas: Oct.

C. Seleriana Harms. 1n. sp. (Sect. Chamæsennu); fruticosa glabra; foliis petiolatis, multijugis (circ. 13-15-jugis); foliolis brevissine petiolulatis rel subsessilibus, lanceolatis vel angustissime ellipticis rel lanceolatooblongis vel oblongis, apice obtusis vel acutis, mucronulatis, glabris; stipulis semicordatis, apice longe oblique acuminatis, caducis; racemis elongatis, multifloris, glabris, bracteis glabris sepalis subsimilibus, alabastra involucrantilus; sepalis glabris obtusis; petalis obovatis, brevissime unguiculatis, rotundatis, brunneo-nervatis; staminibus perfectis 7,2 eorum quan ceteri pluries majoribus; ovario glabro; legumine breviter stipitato, lineari, compresso, plano, apice rotundato, versus stipitem acuto, linea media ad singula semina verrucoso-elevato; seminibus numerosis, transrersis.

Kahler Strauch. Blätter sehr lang, vieljochig (20-30 cm. lang oder noch länđ̛̣er).

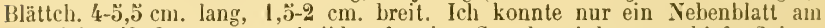
Material auffinden, von etwa halbherzförmiger Gestalt, mit langer, schiefer Spitze, in Ganzen etwa $15 \mathrm{~mm}$. lang. Trauben 10-15 $\mathrm{cm}$. lang. Blüthenstiele $7-12 \mathrm{~mm}$. lang. Bracteen $2 \mathrm{~cm}$. lang. Knospen von grossen, später abfallenden Bracteen umhüllt, Kelchblätter $20-22 \mathrm{~mm}$. lang, Blumenblätter etwa bis $200 \mathrm{~mm}$. lang oder noch länger (bis $30 \mathrm{~mm}$.). Hïlsen schwärzlich, Stiel $50-8 \mathrm{~mm}$. lang, die eigentliche Hülse 8-10 cm. lang, 10-12 mm. breit, aussen mit feinen den Querfächern entsprechenden Linien; in der Mitte geht jedes Querfach in einen vorragenden Buckel oder Knoten aus. Blumenblätter am Herbarmaterial gelbweiss, mit dunkler feiner Aderung. Blüthen (nach C. et E. Seler) gelb.

Halitat in Mexico, in prov. Chiapas in fruticeto apud Tonali: Sel. n. 2063 ; et in Guatemala, in dept. Santa Rosa ad Frajanes in $1000 \mathrm{~m}$. altitud.: J. Jonn. Smith n. 6115 (leg. Heyde et Lux). - Flor. et fruct. in Mex. : Febr.

Die Guatemala-Pflanze wurde von M. Micheli als Cassia reticulata Willd. bestimmt, von der sie jedoch durch die kahlen Blätter hinreichend verschieden ist. Wie neue Art dürte in die Gruppe Picta Bth. gehören. C. picta Don hat nur 4-6 jochige Blätter. Für C. Nicaraguensis Bth. werden grosse Nebenblätter angegeben. Nach der kurzen Diagnose (Bth. MIon. Cass., 552 n. 155) dürfte diese Art jedenfalls der unsrigen am nächisten kommen, jedoch besitzt sie vermutlich grössere Nebenblãtter.

\section{C. sericea Swartz.}

Hab, in Guatemala, in dept. Huehuetenango, in distr. Nenton, inter Laxackanal et Quen Santo, in terra ferrigera : Sel. n. 2680. - Flor. : Aug.

\section{Tagera L.}

Hab. in Guatemala, in dept. Salamá, in silva montosa inter Canoa el Llano grande : Sel. n. 2111. - Flor. : Dec.

\section{C. tristicula II. B. K.}

1Ial. in Mex., in prov. Chiapas in pratis iuxta Conitan: Sel. n. 3060. Flor. : Ang. 
Lrameria cinerea Schaner.

Hab. in Mex., in prov. Oaxaca, in distr. Nochistlan, in Canada infra Cuauhtlilla : Sel. n. 1501. - Flor. : Nov.

\section{Parkinsonia aculeata $\mathrm{L}$.}

Vulg. : "guichi-belle " (zapot. $=$ "Feuerdorn ).

Hab. in Mex., in prov. Oaxaca in distr. Tehuantepec, ad lagunam apud La Miztequilla : Sel. n. 16I7. - Flor. : Jan.

Hamatoxylon Brasiletto Karst.

Vulg. "brasil ".

Hab, in Mexico, in prov. Oaxaca in distr. Tehuantepec in collib. et fruticetis siccis al Tequisistlan et ad Laoyaga, et in distr. Juchitan in silva ad Tapana, et in Guatemala, in dept. Chiquimula ad Camotan : Sel. n. 17Ioั, 1774, 2020, 3343. - Flor. : Jan. et Febr.

Casalpinia eriostachys Benth.

Hab. in Mex., in prov. Oaxaca, in distr. Tehuantepec in valle silvatica inter Tequisistlan et Jalapa : Sel. n. 1675̈. - Flor. et fruct. : Jan.

C. exostemma DC.

Vulg. : " yaga-ti ", "guete-règl ".

Hab. in Mlex., in prov. Oaxaca, in distr. Tehuantepec ad La Miztequilla : Sel. n. 1618. - Flor. : Jan.

C. pulcherrima Sw.

Vulg. : " flor de la guacamaya ".

Hab. in Mexico, in prov. Oaxaca ad San Bartolo Yauhtepec et in prov. Chiapas al Tonalà ad fluvium, et in Guatemala, in dept. Zacapa ad San Agustin Acasaguastan : Sel. 1. 173I, 1869, 3292. - Flor. : Dec.-Febr. - Eine Abkochung der Blüthen wird bei Augenleiden und bei Erisipela gebraucht.

SIMARCBACEA II., det. Harms et Losener.

\section{Picramnia Antidesma Sw.}

Vulg. : " chilillo ».

Hab. in Mex., in prov. Chiapas, in distr. Tuxtla Gutierrez in silva apud Hacienda San Miguel : Sel. n. 1808. - Fruct. : Febr.

$P$. spec. cfr. P. Seemanniana Griseb. mss, in herb. Berol.

Hab. in Mex., in prov. Chiapas, in distr. Tonala inter Tapana et La Junta in silvis : Sel. n. 1836. - Fruct. : Febr.

Die Pflanze stimmt mit der in Herb. Berol. unter P. Seemanniana Griseb. liegenden Art genau uberein (Guatemala. leg. Friedrichsthal n. 1320). Grisebach's Name scheint aber niemals veröffentlicht zu sein; ob die Art nun neu ist, oder ob sie mit einer der zahlreichen Tulasne'schen Arten aus Centralamerika identisch ist, vermögen wir wegen mangelnden Vergleichsmaterials nicht zu entscheiden.

Alvaradoa amorphoides Liebm.

Hab. in Mex. in prov. Chiapas in Cuesta supra Chiapa de los Indios (O) et in Guatemala in dept. Zacapa ad Tulumá apud S. Agustin Acasaguastan in vallis fruticetis ( $₫$ !) et in dept. Salamá ad Rancho S. Clemente supra Tocoy-Morazan (우): Sel. n. 2074, 3289, 3290. - Flor. : Dec.-Mart. 
MELIACE.E HI., det. H. Harms.

Suietenia humilis Zucc.

Vulg. : " caoba w.

Hab. in Vex., in prov. Chiapas, in distr. Tuxtla Gutierrez in vallis "Cintalapa " silva circa Hacienda Razon : Se l. n. 1921. - Flor. : Febr.

Trichiliu Havanensis Jacq.

Hah, in Yex., in prov. Chiapas, in distr. Tuxtla Gutierrez, in fruticetis a l Hacienda Petapa : Sel. n. 2111. - Flor. et fruct. : Febr.

\section{CELASTRACEAE.}

\section{Zinowiewia integerrima Turez.}

Hab. in Guatemala, in dept. Huehuetenango, in distr. Nenton, apud Chaculá in silvestribus montanis : Sel. n. 2609. - Flor. viridul. : Apr.

Wimmeria persicifolia Radlk.

Vulg. : "Chapul-izle » (mexik. = "Heuschreckenfaser ").

Hab. in Mex., in prov. Oaxaca iuxta Huauhtlilla : Sel. n. 1506 b. - Fruct. : Dec. 
Extrait du Bulletin de l'llerbier Boissier.

Tome VII. Yo 8. Aout 1899.

\section{PLANTA SELERIANE ${ }^{1}$}

\section{Die von $D^{r}$ Eduard SELER und Frau Cæcilie SELER}

in MEXICO und CENTRALAVERICA gesammelten Pflanzen

Unter Mitwirliung von Fachmännern verö/fentlicht

von

Th. LASENEK

(Suite.)

HIPPOCRATEACE.E II.

Hippocratea Grisebachii Lœes. (= H. verrucosa Griseb. von H. B. K.).

Hab. in Hexico, in prov. Chiapas in distr. Tonalá in silva planitiei inter Tapana et La Junta : Sel. n. 1895. - Flor, virid. : Febr. - Obs. Valde affinis H. celastroidi II. B. K.

H. Seleriana Lœs. spec. nova; ramulis hornotinis brunneis, puberulis; foliis $5-6 \mathrm{~mm}$. longe petiolatis, ellipticis vel anguste ovato- vel obovatoellipticis, margine i. s. manifeste recurvato, interregimo vel integro, basi obtusis vel acutis, apice obtusis vel subrotundatis et breviter levilerque secundum costam implicatis, $\mathbf{4}-\mathbf{7} \mathrm{cm}$. longis, $\mathbf{1 , 6}-\mathbf{2 , 5} \mathrm{cm}$. latis, crasse et rigide coriaceis, asperulis ceterum glabris, supra i. s. cinereo-vel olivaceoviridibus, subtus cinereo-subrufis, costa media supra prominula vel sub-

1 Vergl. Bull. Herb. Boiss. II, pag. כ333-כั66 u. III, pag. 609-629. BULL. HERB. BOIss., août 1899. 
plana, subtus prominula, nervis lateralibus utrinque circ. 6-7 ad apicem versus curvatim ascendentibus, supra obsoletis, subtus prominulis, iuxta marginem reticulatis, reticulo supra manifeste insculpto, subtus prominulo, obsoletiore; capsulis trilobis, applanatis, lobis obovatis, circ. $4,3 \mathrm{~cm}$. longis, $3, \ddot{3} \mathrm{~cm}$. latis, longitudinaliter nervosis, basi marginibus sese tangentibus et paullisper connatis, apice minute excisulis, loculicide medio secundum totam suturam longitudinaliter dehiscentibus, circ. 4-spermis, seminibus samaroideis, planis, testa superne in locellum coriaceum discoideum oblique ovatum embryoniferum incrassata, inferne in alam circ. 3-plo longiorem, membranaceam sub- formem dilatata, margine externo, i. e. ad suturam versus sito paullulum incrassato, interno (ad carpelli marginem versus sito) tenuire, raphe illo propiore quam hoc.

Habitat in Mexico in prov. Oaxaca in collibus aridis fruticigeris iuxta San Bartolo Yauhtepec : Sel. n. 1628. - Fruct. : Jan.

Obs. Videtur affinis H. obstusifolice Roxbg., speciei Indicæ et Alricanæ.

TURNERACEE II., det. J. Urban.

Turnera diffusa Willd.

Hab. in Guatemala in dept. Quezaltenango et Huehuetenango in pineto inter Aguas Calientes et Malacatan et in distr. Nenton in montibus calcareis inter Uaxackanal et Quen Santo et ad Chaculâ : Sel. n. 2903, 3029, 3121. - Flor. : Jun. et Aug.

T. ulmifolia L. var. intermedia Urb.

Hab. in Mex., in prov. Chiapas, in distr. Tonalà ad Tiltepec : Sel. n. 1860. - Flor. : Febr.

T. ulmifolia L. var. Surinamensis Urb.

Hab. in Mex., in prov. Chiapas, in pratis montis Cerro de Tonala : Sel. $\mathrm{n}$. 20อ̆9. - Flor. : Febr.

T. ulmifolia L. var. velutina (Presl.) Urb.

Hab. in Mex., in prov. Oaxaca, in silva montosa inter San Carlos et S. Bartolo Yauhtepec, et in distr. Juchitan ad Tapana, et in prov. Chiapas in pineto montoso ad Cuesta S. Fernando inter distr. Tenalá et Tuxtla Gutierrez: Sel. n. 1697, 20'.5, 1831. - Flor. : Jan. et Febr.

\section{BIAACE.E.}

Cochlospermum vitifolium (Willd.) Spreng (= Bombax vitifolium Willd., Cochlospermun hibiscoides 11. et B., Maximilianea vitifolia (Willd.) Lrb.)

Vul.z. : "quie-riga ", "quie-quèga " (zapot. = alinke Blumen); « huarumbov. "tecomasuchil " (mexic. = "Becherblume $)$; " thor izquierda " (span. = "linke Blume"). 
Hab. in Mexico, in prov. Oaxaca, in distr. Tehuantepec in Cerro Quiengola, in distr. Yauhtepec in collibus aridis silvaticis ad San Carlos, in prov. Chiapas in distr. Tuxtla in fruticetis vallis de Cintalapa apud Hacienda Razon, et in Guatemala in dept. Chiquimula in collibus aridis inxta Camotan et Cliqquimula : Sel. n. 1612, 1680, 1690, 1933, 3319, 3326. - Flor. : Jan.-Febr.

\section{Bixa Oiellana L.}

Vulg. : " achiote" (mexic.).

$\mathrm{Hab}$, in Mexico, in prov. Oaxaca, in distr. Juchitan in planitiei silva apud Tapana : S e I. n. 2012. - Fruct. : Febr.

\section{PASSIFLORACE.E H., det. H. Harms.}

\section{Passiflora foctida L.}

Hab. in Mex., in prov. Oaxaca, in distr. Yauhtepec ad fluvii Rio Tehuantepec ripau infra Totolapam ad Rancho S. Juanico et in prov. Chiapas in distr. Tuxtla ad Ocozuquauhtla: Sel. n. 1670 et 2119 . - Fl. albid. vel. coerul. : Jan.-Febr.

P. fotida L. var.

Vulg. : " pè-pè » (zapot.); " flor de granadita ".

Hab. in Mex., in prov. Oaxaca, in distr. Tehuantepec, in valle Rio Tehuantepec infra Jalapa: Sel. n. 1663. - Flor. corul. et fruct. rubr. : Jan.

P. macrocarpa Mart.

Vulg. : " granadilla ".

Hab. in Mex., in prov. Chiapas, in distr. Tuxtla, in horto Hacienda Razon : Sel. n. 1969. - Flor., petal. purpureo-violaceo-punctat., filament. purpureoviolaceis : Febr.

P. sexflora Juss.

Hab. in Guatemala, in dept. Huehuetenango supra Jacaltenango : Sel. $n$. 314.3. - Flor. albid. : Jun.

\section{LOASACE.E, det. E. GiIg.}

\section{Gironovia scandens $\mathrm{L}$.}

Hab. in Guatemala, in dept. Huehuetenango, ad Nenton : Sel. n. 3213. Flor. : Sept.

Cevallia sinuata Lag.

Vulg. : "Ortigon".

Hab. in Mex., in prov. Nuevo Leon ad Monterey : Sel. n. 1066. - Flor. : Oct.

Hentzelia latifolia Urb. el Gilg.

Hab. in Mex., in prov. Nuevo Leon ad Monterey : SeI. n. 1090. - Flor. : Oct.

Eucride lobata A. Gray.

Hab. in Mex., in prov. Nuevo Leon ad Monterey in Cerro del Obispado : Sel. n. 1112. - Flor. : Oet. 
LYTHRACE.E II., det. E. K ↔ h $\mathrm{e}$.

Lythrum acinifolium Sess. et Hor. a. parvifolium Kortsne.

Hab. in Mex., in prov. Chiapas, in distr. Cliilon, in montilus et silvaticis inter Huitztan el Oxchuc et S. IIartin : Sel. n. 22' 7 et 22:6. - Flor. et fruct. : Mart.

Cuphea arquipetala Cav. var. «. lavicaulis Kirehne, forma b.

Hab. in Guatemala, in dept. Iuehuetenango, in distr. Nenton, ad Chacula in pratis : Sel. n. 2811 . - Flor. : Jul.

C. aquipetala Cav. var. 3 . hispida Kohne, forma a.

Ilab. in Guatem., apud Huehuetenango, in pratis ad pelem pyramidum Cues Zac-uléu : Se 1. n. 3149. - Flor. : Jun.

C. oquipetala Cav. var. $\beta$. hispida Kohne forma b.

Hab. in Mex., in prov. Mexico apud Dos Rios el in prov. Chiapas in distr.

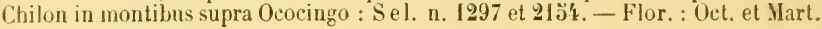

C. angustifolia Jacq.

Ilab. in Mex., in distr. Oaxaca in stagnosis apud Tlaxiaco : Sel. n. 1'43\%. Ftor.: Dec.

C. Balsamona Cham et Schlechtd.

Hab. in Guatemala, in dept. Escuintla at San Andres Osuna, et in dept. Huehuetenango ad Quen Santo in $1300 \mathrm{~m}$. altitud. : Sel. ı. 2:358 et 2786. - Flor. : Ilaj.-Aug.

C. Cæciliz Kohne n. sp. (Sect. Melvilla, Subsect. Erythrocalyx, Ser. „). Cupheæ subuligeræx Kœhne (Ilonogr. n. 203) simillima et ejusdem for'san varietas. Folia latiora (ad $36 \mathrm{~mm}$.), nervo medio subtus sapius purpurascente. Inflorescentix distinctissima folia floralia celerrime decrescentia pilis longis glanduliferis seloso-ciliata, axi pedicellisque densissime glanduloso-hirtellis. Calyx (20-30 mm.) purpureo-coccineus dense glandulosohirtellus. Petala nulla. Staminum 11 dorsalia 2 ceteris multo inferius inserta. Ovula circ. 11 , stylus ovarii $1 \frac{1}{2}$ equans. Cetera ut in C. subuligera Koehne (Engler's Jahrb. II. 408).

Hab. in Mexico, in prov. Chiapas, in distr. Comitan, in silva montana a ripam fluvii "Saconeja ”: Sel. n. 25้8' - Flor. : Mart.

C. graciliflora Kishe.

IIah. in Mex., in prov. Lhiapas, in distr. Chilon, in silva montana inters. Martin et Ococingo : Sel. 11. 21:52. - Flor. : Mart.

C. Hookeriana Walp.

Hab. in Mexico, in distr. Chiapas in clivis apricis arenosis et calcareis apul Iztapa et in distr. "del Centro" in valle "Rio Prospero " apud Hacienda Tierra 
colorada, et in Guatemala in dept. Salanı in silva montana supra Tocoy-Morazan : Sel. n. 208', 2091, 340ż. - Flor. : Dec. et Nart.

C. hyssopifolia H. B. K. forma a.

Hab. in Nex., in prov. Chiapas in distr. Chilon in saxosis ad rivi profunde inculpti marginem in silva montana inter $\mathrm{S}$. Martin et Ococingo : Sel, n. 2132. - Flor. : Mart.

C. leyssopifolia H. B. K. forma h. subrevoluta Kiohne.

Hah. in Guatemala, culta : Sel. n. 2936. - Flor. : Maj.

C. pinetorum Benth.

Hab. in Mex., in prov. Chiapas, in distr. Chilon in pinetis montium inter Oxchue et San Martin, et in Guatemala in dept. Quezaltenango in clivis ad Aguas Calientes : S el. n. 2220 et 3237. - Flor. : Nart. et Sept.

Cuphea procumbens Cav.

Hab. in Hex, in prov. Mechoacan ad Tzintzuntzan et ad Patzcuaro: Sel. n. 1252b. et 1257. - Flor, : Oct.

C. sangnimea Kohne n. sp. (Sect. Diploptychia, Subsect. Leioptychia). Fruticosa. Rami pubescentes ac glanduloso-hispiduli. Folia breviter petiolata opposita, e basi lata rotundata v. subcordata ovata v. oblonga $(3-7 \mathrm{~cm}$ : 1,8-3,6 cm., floralibus usque ad 14:9 mm. decrescentibus), acutiuscula, supra initio strigulosa, subtus strigoso-hirtella v. hispidula, nervorum paribus circ.8. Racemi simplices foliosi; pedicelli solitarii interpeliolares breves. Calys (20-29 mm.) calcare brevissimo munitus, dense glanduloso-hirtellus, intus glaberrimus. Petala 6 valde inaquahra pl. min. intense sanguinea v. flavescenti-sanguinea. Stamina 11 glaberrima. Stylus glaberrimus. Discus horizontalis subtus convexus. Ovula circ. $13-14$.

Hab. in Guatemala, in dept. Huehuetenango, in montium declivilous supra Jacaltenango: Seler n. 2629, et in dumetis Cuesta de la Concepcion : Seler 11. 32200 . - Flor. : Apr. et Sept.

Obs. A plerisque Leioptychice speciebus disco horizontali differt, imprimus a C. corclate R. et P. habitu simili. Proxima C. Nelsoni Rose (Contrib. U.'S. Nat. Herb. V. 3, p. 137 t. 15, 1897) Mexicanæ. cujus discus ipse queque horizontalis, folia vero basi subangustata minora, ovula 10 . An ejusdem varietas?

C. Seleri Kœhne n. sp. (sect. Melanium). Annua. Caulis glandulosohirtellus. Folia breviter petiolata ovata $(3 \mathrm{~cm} .: 1,5 \mathrm{~cm}$.) obtusiuscula, minutim strigulosa el insuper setulosa, nervorum paribus circ. 8-10. Inflorescentia foliosa, simplex videtur, pedicelli brevissimi prophyllis minutis. Calyx ( $7-8 \mathrm{~mm}$.) basigibbus, fauce angustatus subampullaceus, lobo dorsali magno producto, hispidus, fructifer valde ampullaceus. Petala 6 decidua, 2 dorsalia $(2.5 \mathrm{~mm}$.) obtusa, 4 ventralia fere triplo angusliora acutissima. Stamina 11, episepala tubo multo breviora. Stylus glaberrimus semper inclusus. Discus fere horizontalis subtus convexus, ovula :3. Semina (3 mm.) margine obtusa. 
Hab. in Guatemala, in dept. Huehuetenango, ad Uaxackanal in Llano : Seler I. 2841. - Flor. : Aug.

Obs. Species a Cuplea affinitutum Kahne simillima imprimis differt calyce ampullaceo, petalis ventralibus acutis, disco horizontali, seminibus margine obtusis. Inserenda cun C. alfinitutum (cf. Engler's Jahrb. XXIII. Beibl. 57, p. 20) post Monnfr. n. 1(8, ibill. II. 142).

C. subuligera Korhe.

Hab. in Mex., in prov. Chiapas, in distr. Chilon, in montibus inter Oxchuc et San Martin : S el. n, 2171. - Flor. : Mart.

C. utriculosa Korhne.

IIab. in Mex., in prov. Chiapas ad fluvium apud Tonalá : Sel. n. 1874. Flor. : Febr.

C. utriculosa Kohne \% Donnellsmithii Kohne.

Ilah. in Mex., in prov. Chiapas, in distr. Chiapas in saxis humidis ad Hacienda del Calvario et in distr. "del Centro " in lapidibus ad fluvium Rio Ilondo apurl Ilac. del Burrero : Sel. n. 2079 et 2267 . - Flor. : Mart.

C. Wrightii A. Gray.

Hab. in Hex, in prov. Hechoacan ad Tzintzuntzan : Sel. n. 1952 a. Flor. : Oct.

IIeimia salicifolia Link.

Hab. in Mex., in prov. Nuevo Leon in Cerro del Obispado apud Monterey : sel. n. 110 ä et 1109 . - Flor. : Oct.

ARALIACEA, det. H. Ha r ms.

Oreopanax capitatus Dene. et Pl., forma foliis paullo magis cordatis.

Vulg. : "K'ab-choh » (Sprache der Chuh); " pata de leon ».

Hab. in Guatemala, in dept. Huehuetenango, in distr. Nenton in collibus calcareis ad Quen Santo et inter Charuial et Chacula in 1 ' 00 m. altitud. : S'el. $n$. 2669 et 3139. - Flor. : Jun. et Jul.

U. Talapensis Dene. et Pl.

Hab. in Mex, in prov. Chiapas, in clistr. Chilon in silva montana inter Huitztan et Oxchuc: SeI. n. 2224. - Fruct. : Mart.

Gilibertia arborea March.

Hab. in Mex., in prov. Chiapas in distr. Tonala in silva circa Arroyo in Hacienda Los Amates et in silva montana ad Cuesta San Fernando inter distr. Tonala et Tuxtla: Sel. n. 1801 et 1919. - Flor. : Febr.

Aralia humilis Cav.

Ilab. in Mexico, in prov. Chiapas ad Comitan, et in Fuatemala, in dept. Hueluetenango in distr. Nenton in montibus calcareis apricis ad Uaxackanal : Sel. n. 3046 et 3030 . - Flor. : Aug.

\section{POLEMUNIACE.E II.}

Cobcra macrostemma Ruiz et Pavon.

Ilab. in Guatenala, in cupressetis et bambusetis al Chixoy apul Teepant 
Guatemala in $3000 \mathrm{~m}$. altitud. et in dept. La Antigna ad San Lucas : Sel. n. 2993 et $2 ! 32$. - Flor. pallide flavi : Sept.-Oct.

Bonplandia geminiflora Cav.

Hab. in Mex., in prov. Morelos in distr. Cnernavaca prope Xochicalco : Sel. n. 400 . - Flor. : Dec.

\section{Loeselia ciliata $\mathrm{L}$.}

Hab. in Mex., in prov. Oaxaca in distr. Juchitan apud Tapana et in prov. Chiapas in distr. Tuxtla in horto Haciendæ Razon : Sel. n. 1786, 199.̈, 1854. Flor. albidi vel. pallide flavi : Febr.

L. glandulosa (Cav.) G. Don.

Vulg. : " spinacilla ".

Hab. in Mexico, in prov. Oaxaca in pineto ad Cueva de las Calaveras apud Tlaxiaco et in silvaticis montanis inter San Carlos et San Bartolo Yauhtepec, in prov. Chiapas in distr. Tuxtla in Hacienda Petapa, in Guatemala in dept. " del Centro" in pineto montano apud Chiquin : Sel. n. 1440, 163̈4, 193I, 2486. Flor, rubell. vel rosei vel roseo-lilacini : Dec.-Febr.

L. intermedia Lœs. sp. nova; ramulis glanduloso-puberulis; foliis circ. 1-3 mm. longe petiolatis, ovato-oblongis usque sublanceolatis, argute serratis, denticulis mucronatis, basi cuneatis, apice acutis, circ. $1,2-1,8 \mathrm{~cm}$. longis, $0,1-0,6 \mathrm{~cm}$. latis, utrinque glanduloso-puberulis; floribus in foliorum ad ramuli apicem versus diminutorum axillis solitariis, pedicellis gracilibus circ. $6 \mathrm{~mm}$. longis, prophyllis circ. $7-8$ sub floribus ipsis dense congestis et hypanthium formantibus, singulis exterioribus foliaceis lanceolatis vel lineari-lanceolatis, glanduloso-pilosis, aristato-serratis acutis, costa et nervis manifeste prominentibus, interioribus hyalinis, anguste ovato-deltoideis, appresse aristatis apice anguste acutis, omnibus circ. 't-6 $\mathrm{mm}$. longis; calyce albido hyalino, tubuloso tenuiter membranaceo circ. $4 \mathrm{~mm}$. longo, כ̈-lobo, lobis erectis, tubo ipso brevioribus, manifeste nervosis, nervis in aristulas tenues desinentibus; corollæ tubo incluso, lohis rotundatis, cuneatis, i. vivo purpureis, sed i. sicco postquam in aqua coctis violaceis; staminibus breviter exsertis, ovario 3 -loculari, loculis 1-ovulatis, stylo longo filiformi, apice breviter 3 -loho.

Lœselia glandulosa Dammer in Lœs. Pl. Sel. I. p. 26 (5ั58) non G. Don.

Habitat in Mexico, in prov. Oaxaca in Cerro de la Soledad : Sel. n. $1343 b$., 1344. - Flor. : Nov.

Obs. Species intermedia est inter $L$. glandulosam G. Don. et L. cœruleam G. Don. An planta hybrida?

L. cœrulea (Cav.) G. Don.

Hab. in Hex., in prov. Oaxaca in Cerro de la Soledad: Sel. n. I343a. Flor. : Nov. 
L. coccinea G. [1on.

Vulg. : "spinacilla".

IJab. in Mex., in prov. Mechoacan in clivis montis Calvario iuxta Pátzcuaro et in prov. Chiapas in distr. "del Centro " in silv. montan. inter Iztapa et Cinacantan : Sel. n. 120't et 2089. - Flor. ignei : Nov.-Hart.

\section{HYIDROPHILLACEE II.}

Phacelia pimpinelloides A. Gray.

Hab. in Guatemala in dept. Quezaltenango in monte Chi Lahuh Quieh in agrestibus : Sel. n. 2896. - Fl. : Jun. - Det. Donn. Smith.

Nama jamaicense L.

Hab. in Guatemala, in dept. IIueliuetenango in distr. Nenton ad Caxackanal : Sel. n. 2859 et 3193 . - Flor. albid. : Aug.

N. dichotomum Choisy.

Hab. in Mex., in prov. Oaxaca in fundamentis domuum antiquarum in Teposcolula : S el. n. 150\%4. - Fruet. : Dec.

Stark wohlriechend.

N. dichotomum Choisy forma latisepalum Los. forma nova, humilior et gracilior, florilus pancioribus, sepalis apice magis dilatatis.

Ilab. in Mex., in prov. Oaxaca in clivis humidis sub saxa calcarea ad Tlaxiaco : Sel. n. 1463. - Flor. et fruct. : Dec.

Wigandia Caracasana II. B. K. forma.

Hab. in Mex., in distr. fœederali ad Coyouacan : Sel. n. 1333. - Flor. lilac. : Nov. - Præterea nultoties olsservata in Canada "Tecomaraca " usque ad vallem Oaxaca.

\section{Hydrolea spinosa L.}

IIab. in Mexico, in prov. Oaxaca in distr. Juchitan in alveo fluvii ad Tapana et in Guatemala in dept. Izabal in fluvii "Rio Motagua " ralle apud Los Amates: Sel. n. 1783 et 3373 . - Flor. : Jan.-Febr.

\section{LABIATEI.}

Teucrium cubense $\mathrm{L}$.

Hab. in Mexico in prov. S. Luis Potosi, in distr. Cindal del Maiz prope Gallinas et in prov. Nuevo Leon iuxta Monterey : Sel. 11. 770 et 1010. Flor. : (Oet.-Febr.

Scutellaria purpurascens Sw.

Hah. in Mex. in prov. S. Luis Potosi, in distr. Taucanhuitz prope Tampanolon : Sel. n. 192.

Sc. Seleriana Lors. sp. nova; caule erecto, ramosissimo, breviler pubescente, obsolelo '1-gono; foliis remotis $7-13 \mathrm{~mm}$. longe petiolalis, peliolo 
tenui, pubescente, late ovatis, obtusis, crenatis, basi late cuneatis vel subtruncatis, supra puberulis, subtus pubescentibus, nervis utrinque circ. 2-3, subtus prominulis, lamina circ. $12-18 \mathrm{~mm}$. longa, $8-12 \mathrm{~mm}$. lata, floralibus gradatim minoribus et brevius petiolatis, addito petiolo usque $10 \mathrm{~mm}$. longis, inflorescentiis racemosis floribus, ut videtur, oppositis, pedicellis pubescentibus, 3-4 mm. longis, calycibus hirtellis, vix $2 \mathrm{~mm}$. longis, scutello circ. $1, . ّ \mathrm{~mm}$. longo, in fructu usque $5 \mathrm{~mm}$. longo, corollis extrinsecus præcipue apice breviter villosulis, pallide purpureis, sub anthesi $12-103 \mathrm{~mm}$. longis, fauce sensim dilatato, labio superiore 3-lobo, lobis margine sub-incrassatis et crenulatis, medio cucullato, vix $\mathbf{2} \mathrm{mm}$. longo, labio inferiore porrecto, $3,5 \mathrm{~mm}$. diam., rotundato, subintegro, apice obsolete excisulo, staminibus ' d didynamis, corollæ tubo insertis, filamentis styloque apice recurvatis el labii superioris galea inclusis; disco obliquo latere anteriore gynophorum gerente, nuculis sub anthesi glabris.

Habitat in Guatemala, in dept. Huehuetenango, in collibus silvaticis ad Uaxackanal inter lapides calcareos in 1200-1300 m. altitud. : S el. 11. 2799. - Fl. et fruct. : Jul.

Obs. Species ad $\$$ Vulgures Benth., C Cuneatce Briq. pertinere videtur.

Sc. lutea J. Donn. Smith.

Hab. in Guatemala, in dept. Salaná ad Santo Thomas in pinetis : Sel. n. 2'41 et 3406. - Flor. : Dec.

Sc. chalicophila Los. sp. nova, basi ramosa, ramulis ipsis simplicibus, tetragonis, sub lente valida brevissime pulvereo-puberulis; foliis remotis, brevissime ( subintegris, basi acuta vel late cuneata, glabris vel subglabris, $18-30 \mathrm{~mm}$. longis, 7-12 mm. latis, costa tantum subtus iuxta basin minutissime et brevissime pulvereo-puberula, nervis utrinque $\underline{\simeq}-3$, subtus prominulis, floralibus gradatim minorilus; inflorescentiis racemosis, floribus oppositis; pedicellis breviter puberulis, circ. $2 \mathrm{~mm}$. longis; calycibus subglabris vel sub lente valida hinc inde brevissime et parce pulverulento-puberulis, circ. $\mathbf{2}, \ddot{3} \mathrm{~mm}$. longis, scutello vix $\mathbf{2} \mathrm{mm}$. longo, in fructu usque pæne $5 \mathrm{~mm}$. longo; corollis extrinsecus glanduloso-villosulis, cœruleis, circ. $15 \mathrm{~mm}$. longis, fauce sensim dilatato, labio superiore sub-galeato, 3-lobo. lobis margine \pm repandis, pæne $2 \mathrm{~mm}$. longis, labio inferiore paullum deflexo atque longitudinaliter replicato, obsolete crenulato-lobulato, rotundato, circ. 4,ö mm. diam.; staminibus 4, didynamis, fauci corollæ insertis, filamentis styloque apice recurvatis galea inclusis, disco oblique conico. in gynophorum angustato, nuculis sub anthesi glabris. 
Ifabitat in Guatemala, in dept. Inehuetenango inter Chaculả et Uaxachanal in montibus silvigeris calcareis in 1400-1500 m. altitud. : Sel. n. 282't et $\mathrm{n}$. 3119. - Flor.: Jun.-Jul.

Ols. Species ad $\$$ Vulgures Benth., $F$. Circlericulatce Boiss, pertinens.

Marrubium vulgare $\mathrm{I}$.

Vuly. : " amor seco ".

Iral, in Mexico prope Aguas Calientes, in prov. Mexico, in distr. Chalco prope Amecameca, in prov. Oavaca prope Teposcolula : Sel. I1. 498, כ̈71, 1603. Flor. : Nov.-Dec.

\section{Brunella vulgaris $\mathrm{I}$.}

Ilal, in Mexico, in prov. Hidalgo prope Zacualtipan et prope Matlatengo : Sel. 11. 14't et 6öI, et in Guatenala in depart. Huehuetenango ad "Cnesta de la Concepcion $"$ in 1600-2000 m. altitud. vulgaris : S e I. n. 2876. - Flor. in Hex.: Maj., in Guatem. : Sept.

\section{Leonurus sibiricus L.}

IIab. in Guatemala, in dept. Escuintla ad la Rocliela apud San Andres Osuna et in dept. Alta Vera Paz in Coban in hortis et al vias : Sel. n. 2459 et 3412. Flor. : Yov.-Dec.

Salviu privoilles Benth.

Hab. in Mex., in prov. Mechoacan, iuxta Tzintzuntzan in campestribus : Sel. n. 1238, - Flor. pallide corul. : Oct.

S. tiliifolia Vahl.

Ilah. in Mexico, iuxta Oaxaca in ruderalibus, et in Guatemala, in dept. Hueluetenango, in distr. Jacaltenango, ad Todos los Santos : Sel. n. 1330 et $27 i 1$. - Flor. corul. : Sept.-Yov.

\section{S. lanceotata Willd.}

Lab. in Mex., prope Zacatecas, in prov. S. Luis Potosi ad lacum siccum iuxta vian ferream, in prov. Hechoacan ad Tzintzuntzan in campestribus : Sel. $\mathbf{n}$. 539, 1I26, 1229 a. - Fl. pallide corul. : ()et.-Nov.

s. lanceolata Willd. forma.

Hal. in Mex., in prov. S. Luis Potosi iuxta Venado : Sel. n. 1123.

S. angustifolia Cav. forma ad var. glabram Briq. accedens.

Hab. in Guatemala, in dept. Huehuetenango in distr. Nenton ad Chaculà in collibus silvaticis in 1600 m. altitudine : Sel. n. 2991. - Flor. corul. : Aug.

S. angustifolia Cav. var. glabra Briq. mss. in herb. Berol. ramulis glabris, calycibusque breviter puberulis.

Hal. in Mex., in prov. Mechoacan iuxta Tzintzuntzan et in prov. Chiapas in distr. Tuxtla ad Ocozuquauhtla in locis apricis : Sel. n. 1230 et 1930. - Flor. ecerul. : (0.t.-Febr.

Salvia lavanduloides Kunth.

Hab. in Mex., in prov. Hechoacan in elivis supra Monte Calvario apud Patzcuaro et in jrov. Chiapas in elivis arenosis el calcareis apul Iztapa, in distr.

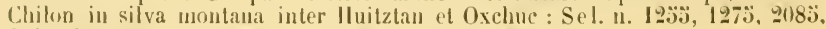
2147, 2137. - Flor. corrul. : Oct.-Yov.; fruct. : Hart.

S. nana kiunth.

llab. in Mexico, in prov. Oaxaca, in distr. Etla in Cerro de Buena Vista et 
in Guatemala in pineto inter Aguas Calientes et Malacatan : Sel. n. 100 et 2891. — Flor. : Jun.

S. glechomifolia Kunth.

Hab. in Mex., in prov. Hidalgo prope Zacualtipan : Sel. n. 881. - Flor. : Maj.

S. Hispanica.L.

Hab. in Mex., in prov. Jalisco, prope Serrano : Se l. n. 5̈75. - Flor. : Yov.

s. Xalapensis Benth.

Hab. in Mex., in prov. Chiapas in distr. Tuxtla in Hacienda Petapa : Se l. 1. 1959. - Flor. corul. : Febr.

S. polystachya Orteg.

Hab. in Mex., in distr. foderali in Cerro de Iztapalapa et in prov. Mechoacan iuxta Pátzeuaro: Sel. n. $428,463,1276$. - Flor. pallide cœrul. : Nov.-Dec.

S. angulata Benth.

Hab. in Mex.. in prov. Mechoacan ad Tiripitio el ad Pátzcuaro : Sel. n. 1149 et 1237. - Flor. albid. vel obscure corul. (calyce subatro) : Oct. - Ex descript. determinata.

\section{S. ballotiflora Benth.}

Hab. in Mex., in prov. Nuevo Leon in distr. Monterey in collibus saxosis et apricis Cerro del Obispado : Sel. n. 1089. - Flor. pallide corul. : Oct.

S. semiatrata Zucc.

Hah. in Mex., in prov, Oaxaca in distr. Nochistlan in Canarla supra El Parian : Se 1. n. 1520. - Flor., calyce violaceo, corolla olsscure corulea : Nov.

S. amarissima Ort.

Hab. in Mex., in prov. Oaxaca prope Etla : Sel. n. 84. - Flor. : Jun.

s. Lindenii Benth.

Hab. in Mex., in prov. Chiapas in distr. del Centro in valle fluvii "Rio Hondo " apud Hac. del Burrero, in saxosis et in distr. Chilon inter Huitztan et Oxchue in silva montana : Sel. n. 2107 et 2248 . - Flor. carnei vel rubri : Hart.

S. involucrata Cav.

Hab. in Guatemala, in dept. Salamá in silva ad Santa Rosa : Sel. 11. 3297. Flor. rub.: Dec.

S. microphylla Kunth (S. Grahamii Benth. vix varietas mediocris S. microphylle Kunth).

Hab. in Mex., in prov. Hidalgo prope Zacualtipan et in distr. foederali in Cerro de Iztapalapa et prope Tacubaya : Sel. n. 168, 427, 430, 432, 462. - Flor. et fruct. : Nov, et Maj.

S. cyanea Benth.

Hab. in Guatemala, apud Qnezaltenango in monte trachytico Chi Lahuh Quieh : Sel. n. 2944. - Flor. obscure corul. : Jun.

\section{S. Mexicana L.}

Hab. in Mex., in prov. Nechoacan supra Monte Calvario apud Pátzcuaro: Sel. n. 1193. - Flor., calyce pallide viridi, corolla obscure corulea : Oct. 
S. purpurea liav.

Ilah. in Mex., in prov. Mechoacan prope Tzintzunlzan et in clivis supra Monte Calvario apud Patzcuaro et in prov. Chiapas in distr. Chilon in montibus inter Oxchuc et San Martin ad rivulos et in pratis : Sel. n. 1198, 1203, 1280, 2261. - Flor. purpurei vel purpureo-violacei : Oct--Mart.

S. affinis Cham. et Schlechtıl, specimen ad S. purpuream Cav. vergens.

Ilals, in Guatemala iuxta Chimaltenango in fruticetis : Sel. n. 2338. Fl. purpur. : Sept.

s. cinnabarina Mart. et Gal.

Hah. in Guatemala, in dept. Chinaltenango in Sierra Santa Elena apud Tecpam Guatemala in cupressetis : Se 1. n. 2336. - Flor. rubr. : Sept.

S. coccinea $\mathrm{L}$.

Hab. in Mex., in prov. Nuevo Leon in Cerro del Obisparlo iuxta Monterey : Sel. 11. 1073. - Flor. : Oet.

S. coccinea L. var. pseudococcinea (Jacq.) Los. (=S. psendococcinea Jacq.)

Vulg. : " mirto".

Hab. in Mex., in prov. S. Luis Polosi, in distr. Tancanhuitz prope Tanquian, et in distr. Ciudaul del Maiz prope Gallinas, et in prov. Nuevo Jeon iuxta Monterey : S e I. n. 273, 716, 106I. - Flor. vivo-jubri : Oct.-Hart.

S. vitifoliu Benth.

Hab. in Mex., in prov. Oaxaca prope Etla : Sel. n. 8\%̈.

s. cacaliifolia Benth.

IIab. in Guatemala, in dept. Alta Vera Paz prope Coban : Sel. n. 2'133. Flor. corrul. : Dec.

S. Alamosana Rose vel affin.

Ilab. in Mex., in prov. Nechoacan, in clivo supra Monte Calvario apud Patzcuaro : Se I. n. 1229 b. - Flor. corul. : Nov.

\section{Lepechinia spicata Willd.}

Hal). in Guatemala, in dept. Huehuetenango prope Aguas Calientes in canpestribus et al rivulorum ripas arenosas : Sel. 11. 2767. - Flor. albid. : Sept.

L. Schiedeama (Schlechtıl.) Vatke (=Stachys Schiedeana Schlechld. in linnar VII, 18:32, p. 398, Lepechinia procumbens Benth. Lab. p. 41: [Мaj 18:31]).

Ilab. in Mexico, in prov. Hidalgo prope Zacualtipan : Se l. n. 899. - Fl. et fr. : Maj.

\section{Hetleoma costata Hems].}

Ilab. in Guatemala, in dept. Inehuetenango, iuxta Chacula in collibus calcareis in $1600 \mathrm{~m}$. altitud. : Se 1. 11. 3121. - Flor. lilac. : Jun.

Salureia Bronnei (Sw.) Briq. forma transit. al s. xalapensem (Kunth.) Briq.

Hab in Mexico, in prov. Chiapas ad S. Martin : Sel. n. 2131, et in Guatemala in lept. Huehuetenango ad Clacula in fiuticetis et inter ouliliciorum fundamenta veterum : Sel. n. 3118. - Flor.: Mart.-Jun.

IIypt is tomentosa Poit.

Ilab. in Mexico. in prox. Chiapas in distr. Tuxtla in vallibus apertis Iaciendx Petapa : Sel. 11. 1958. - Flor. pallide corulei : Fehr. 
H. tomentosa Poit. vel affinis, foliis paullulo latioribus, indumento paullulo densiore diversa.

Hab. in Mexico, in prov. Oaxaca, in distr. Tlacolula in Canada supra Totolapam : Sel. n. 17833. - Frutices alti, florib. pallide cœrul. : Jan.

H. albida H. B. K.

Hab, in Mexico, in prov. Vera Cruz, in distr. Ozuluama prope Pánuco : Sel. n. 948. - Flor. : Mart.

H. albida H. B. K., forma inflorescentiis laxioribus paullulum recedens.

Hab. in Mexico, in prov. Jalisco al vulcani apud Colima siti pedem prope Barranca de Beltran in clivis aridis : Sel. 11. 3'33. - Flor. lilacini : Apr.

H. stellulata Benth.

Hab. in Mexico, in prov. Morelos in distr. Cuernavaca prope Xochicalco, in prov. Oaxaca in distr. Oaxaca ad San Bartolo Yauhtepec in collibus aridis et in Cerro de la Soledad, in Honduras in silvaticis montanis supra Copan : Sel. $n$. $389,1338,1658,3330$. - Flor. alb. dulce fragraut. : Nov.-Jan.

H. verticillata Jacq.

Hab. in Mexico, in prov. Vera Cruz in distr. Ozuluama prope Panuco, in Guatemala in dept. Huehuetenango at Nenton, et in dept. Izabal in valle fluvii "Rio Motagua " apud Los Amates in fruticetis : Sel. n. 68\%, 3208, 3363. Flor, albill. vel albido-rosei : Sept.-Apr.

H. pectinata Poir.

Hab. in Guatemala in municipio ipso in querceto ad Barranca del Zapote: Sel. n. 2470. - Flor. lilac. : Nov.

H. urticoides Kunth.

Hab. in Mexico, in prov. Chiapas in distr. Chilon in clivo supra Ococingo : Sel. n. 2I34. - Flor. pallide corul. : Mart.

IF. lilacina Benth. DC. Prod. XII, p. 123 (an etiam Schiede et Deppe?).

Hab. in Guatemala, in dept. La Antigua ad San Lucas frequens : Sel. n. 2'23. - Flor. aromatici, pallide rosei usque albidi : Oct.

H. mutabilis (Rich.) Briq. var. spicata (Poit.) Briq. vel affinis.

Habitat in Mexico, in prov. Oaxaca ad fluvii ripam apud Tonalá et in Honduras supra Copan in pineto-quercetis : Sel. n. 1996 et 3370. - Flor. fragrant. pallide corul. : Jan.-Febr.

H. capitata Jacq.

Hab. in Guatemala in dept. Escuintla, iuxta S. Andres Osuna al Cucunya : Sel. n. 252'

H. capitata Jac,. var. Guatemalensis (Vatke mss.) J. Donn. Smith in schedulis.

Hab. in Guatemala, in dept. Escuintla, inxta S. Andres Osuna ad rivulum apud Cucunya : Se 1. n. 2520. - Fl. albid. : Maj.

H. brevipes Poit. var. robusta Los. var. nova; tota planta robustior, foliis crassioribus anguste oblanceolatis, capitulis præcipue fructiferis multo maioribus usque $2.2 \mathrm{~cm}$. diam. (forsan species propria).

Hab. in Mex., in prov. Chiapas, in distr. Chilon, ad San Martin in clivis et silvaticis montanis : Sel. n. 2 Iวั3̈ et $2264,-$ Flor. albid. usque violac. et fruct. : Mart. 
H. florida Benth. vel affinis.

Hab. in Mex., in prov. Morelos, in distr. Cuernavaca prope llacienda S. Gaspar : Sel. n. $311,-$ lilor. : Hec.

II. recurvala Poit.

IJah. in Mex., in prov. Oaxaca ad fluvii ripam apud Tonalá : Sel. n. 1997. Flor. allicl. : F(b)r.

Ocimum carnosum Link et Otto.

Hal, in Mexico prope (Grizaba : Sel. n. 838 et 919. - Flor. : Jul.

O. micranthum Willd.

Hab. in Hexico, in prov. S. Luis Potosi, in distr. Tancanhuitz prope Tampanolon, et in prov. Chiapas in distr. Tuxtla ad Cintalapan et Oeozuquauhtla : Sel. n. 23.̈, 189̈, 19\%̈. - Flor. : Felor.-llart.

GESNERACEE det. John Donnell Sinith.

Tussacia spec. forsan. nova.

Hab. in Mex. loco natali accuratius non indicato : Sel. n. 923. - Det. Laes. Alloplectus telragonus Hanst.

IIab. in Guatemala, in dept. Huehuetenango, iuxta Yalambohoch in humida silva primeva : Sel. n. 3218 . - Fl. : Aug.

Achimenes grandiflora DC.

Hab. in Guatemala, in dept. Huehuetenango ad Cuesta de la Concepcion, in umbrosis saxis calcareis et inter Nenton et San Andres in pineto ad umbrosum rivuli margineın : Sel. n. 3247 et $3280 .-$ Fl. : Sept.

Heppiella ovata Klotzsch et Hanst.

Hab. in Guatem., in dept. Huehuetenango in distr. Jacaltenango in clivis fruticigeris apud San Martin : Sel. n. 3191. - Flor. : Sept. ${ }^{1}$

Kohleria Ieppeana (Cham et Schlechtd.) Fritsch (=Isoloma Deppeana Hemsl.)

Hab. in Guatem., in dept. Alta Vera Paz ad Santa Cruz apud Coban : Sel. n. 2'139. - Flor.: Ilec.

K. elegans (Decsne.) Los. (= Moussonia elegans Decsne.)

Hab. in Mexico, in prov. Chiapas in distr. Chilon in clivo supra Ococingo : Sel. n. 2180. - Flor.: Mart. - Det. Les.

Gesneria Warsceviczii IIanst.

Hab. in Gnatemala, in dept. Huehuetenango apnd Quen Santo : Sel. n. 267I. - Flor. : Aug.

1 Ein Vergleich mit dem Hansteinchen Original aus Venezuela zeirl indessen, dass es sich um eine andere Art handeln muss, die vielleicht neu ist. (Ob die sielersche Pllanze ïberhaupt zn Heppiella gehört, erscheint mir ebenfalls zweifelhaft. Th. Larsener. 
ACANTHACEE III., det. G. Lindau.

Elytraria squamosa (Jaci.) Lindau (= Tubiflora sq. (Jacq.) 0. Kitze.).

Vulg. "Un pie".

Hal, in Nexico, in prov. Oaxaca, in distr. Juchitan, ad Tapana in locis apertis. in prov. Chiapas in distr. Tuxtla, in Hacienda Razon et in distr. Tonala inter Tapana et La Junta in fruticeto arido, ibique ad Tonala ad fluvii ripam, atque in Guatemala in collibus siccis ad Chiquimula : S e 1. n. I787, 1863, 2021, 2018, 3374. - Fl. et fr. : Jan. et Fehr.

Blechum grandiflorum OErst.

IIab. in Mex., in prov. Chiapas, in distr. Tuxtla ad Ocozuquauhtla ad rivulum : Se 1. n. 2123. Flor. : Febr.

\section{Dyschoriste bilabiata (Seem.) 0. Kitze.}

Hab. in Mex., iuxta Oaxaca in monte Alban : Sel. n. 1733. - Flor. : Dec. D. crinita (Nees) 0. Ktze.

Hab. in Guatemala, in dept. Huehuetenango in pratis iuxta Chaculá in $1600 \mathrm{~m}$. altitud., ibique in pinetis et quercetis in solo calcareo, et in pinetis inter Aguas Calientes et Malacatan (inter dept. Hueliueten. et Quezaltenango) : Sel. n. 2812, 2946, 2989, 3158. - Flor. : Jun.-Aug.

D. ovata (Cav.) 0. Ktze.

Hab. in Guatemala, in dept. Quezaltenango in distr. Ziha, in clivis fruticigeris al Aguas Calientes : Sel. n. 3112. - Flor. : Sept.

D. Quitensis (H. B. K.) 0. Ktze.

Hab. in Mex., in prov. Mechoacan in via ferrea iuxta Acámbaro : Sel 11. 11306. - Flor. : Oct.

\section{Ruellia geminiflora $\mathrm{H}$. B. K.}

Hab. in Mlex., in prov. Oaxaca, in distr. Nochistlan, in Cerro del Pueblo viejo ad Huauhtlilla in silva montosa in solo calcareo : Sel. n. Iö70. - Flor. : Dec.

R. geminiflora H. B. K., vel affinis.

Hab. in Mex., in prov. Chiapas, in distr. Tuxtla in horto Haciendæ Razon : Sel. n. 1813. - Flor.: Febr.

\section{R. Hankei Nees.}

Vulg. : "Yerva de novillo ».

Hab. in Mexico, in prov. Chiapas, in distr. Tonalá, in silva ad lagunæ marginem prope Paredon, inque distr. Tuxtla, in Cuesta infra Hacienda Petapa, et in prov. Oaxaca, in distr. Juchitan in pratis ad lagunam inter Chicapa et Izhuatan, et in Guatemala, in dept. centrali, in silva montana apud Chiquin, iuxtaque Chiquimula in collibus siccis, et al Camotan : Sel. n. 1839, 1906, 1987, 2472, 3332, 3342. - Flor. et fruct. : Dec.-Febr.

R. megasphora Lindau in Bull. Herb. Boiss. 1895 p. 364.

Hab. in Mex., in prov. Chiapas inter distr. Tonalá et Tuxtla in pinetis montanis iuxta Cuesta San Fernando et in Cerro de Tonalá : Sel. n. 1918 et 2000. Flor. et fruct. : Felor. 
R. paniculata $\mathbf{L}$.

llab. in Hex., in prov. (Jaxaca, in distr. Teluantepec, ad lagunam nunc exsiccatam apul Iliztequilla : Sel. II. I616. - Flor. et fruct. : Jan.

R. pilosa Pav.

Hab. in Guatenala, in dept. Huehuetenango. in distr. Yenton, in pratis iuxta Chacula in 1300-1600 m. altitud. : Sel. n. 998 '. - Flor. : Jul.

R. Uuberosa L.

Hab. in Mex.. in prov. Nuevo Leon al Monterey in locis apertis. ibigue in Cerro del Obispado, in prov. Oaxaca. in distr. Jnchitan in silva locis apertis ad Rancho Las Anonas : Sel. n. 1074, 107:3, 1103, 1982. - Flor. et fruct. : Oct.

Barlerin micans Nees.

Hab. in Mexico, in prov. Chiapas, in distr. Tuxtla in fruticetis Hacienda Petapa, et in Guatemala in dept. centrali, in silva montana apul Cliquin : Sel. II. 1903 et 2'71. - Flor. : Dec.-Febr.

\section{1 phelandra Deppeana Schlechtd.}

Ilab. in Guatem., in dept. Chimaltenango in pede rulcani "del Fuego " arl Paloverde : S e I. I. 2426. Flor, et fruct. : Nov.

Pseuderanthemum biceps Lindau, nov. spec. Caulis subtetragonus, lineis ฯ pilosus, tum glabratus, cystolithis minutis dense striolatus. Petioli '-̋̈ mm. longi, tenues, glabri. Folia ovata, apice acuminata, basi maxime oblique angustata, paribus sæpe inæqualibus, usque ad $6 \times 2 \mathrm{~cm}$., sed interdum majora, basi sensim in petiolum angustata, $10 \mathrm{~cm}$. longit. et $4 \mathrm{~cm}$. lat. excedentia, semper glabra, cystolilis siriolata. Spicæ terminales foliis subæquales, axillares multo breviores, breviter pedunculatæ, pubescenles, densifloræ. Braclea lineares, c. $4 \times 1$ mm., bracteolæ $\mathbf{4}, 501 \mathrm{~mm}$, ommes minute glanduloso-puberula. Calycis lobi $11 \times 1 \mathrm{~mm}$., minule glandulosix. Tubus c. $20 \mathrm{~mm}$. longus, basi $1, \check{5}$, apice $2 \mathrm{~mm}$. diam., ad apicem extus

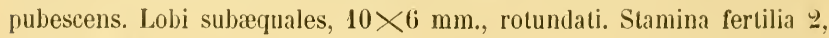
filamentis $1,5 \mathrm{~mm}$. longis, anlheris $3 \mathrm{~mm}$. longis. Staminodia basi filamentis conjuncta, $1 \mathrm{~mm}$. longa, apice subdichotome bicapitata. Pollinis granula typica, subglobosa, c. 50-60 « diam. Ovarium 1,̋ mm. altum. Slylus c. $20 \mathrm{~mm}$. longus. Capsula $12 \mathrm{~mm}$. longa, $4 \mathrm{~mm}$. lata, basi usque ad $1 / 3$ longit. stipitata, apice cuspidata, glabra, 4 sperma.

Hab. in Mexico, in prov. Oaxaca, prope Tlaxiaco ad marginen rivorum : Seler n. 1438. - Fl. et fruet. : Dec.

Am näthsten mit $P$. cuspidatum verwandt, das sich aber durch die dünneren Blülen und die an der Basis viel mehr verschmälerten Blätter ohne weiteres unterscheiden lässt. Durch die 2 köpfigen Staminoiden, sowie die verhältnismăssig kurz gestielte Kapsel aber ausgezeichnet.

l'. species, nimis incompleta, sine foliis.

Hab. in Mex., in prov. Chiapas, in distr. Tuxtla in Hac. Petapa inter gramina alta : Sel. n. 19'tl. - Flor. el fruct. : Felor. 
Tetramerium hispidum Nees.

Hab. in Mex, in prov. Oaxaca in Cerro de la Soledad : Sel. n. 1367. Flor. : Nov.

Odontonema callistachyum (Cham. et Schlechtd.) 0. Ktze.

Hab. in Mex., in prov. Chiapas, in distr. Chilon, ad rivuli profunde incisi ripam umbrosam in pineto montano inter San Martin et Ococingo : Se l. n. 2204. - Fruet. : Mart.

Siphonoglossa forsan S. Pringlei (Rob. et Gr.) Lindau.

Hab. in Mex., in prov. Oaxaca, in distr. Yauhtepec, in vallibus silvaticis siccis ad ripan dextram fluvii "Tehuantepec" ad Rancho de los Pichones: Sel. n. 17566. - Flor. et fruct. : Jan.

Cardiacanthus (?) fragrans Lindau n. sp. Frutex fragrans, ramis teretibus, patenti-pubescentibus, tum glabratis, epidermide solvente, cana, ramulis dense glanduloso-pubescentibus. Folia petiolis usque ad $5 \mathrm{~mm}$. longis, ovata, basi rotundata, apice acuminata, usque ad $4 \mathrm{~cm}$. longa, $1-2 \mathrm{~cm}$. lata, pubescentia pilis glanduligeris intermixtis. Spicæ folia aquantes terminales vel axillares, subsessiles, dense glanduloso-pubescentes, densifloræ. Bracteæ ovatæ, apice rotundatæ, mediæ $10 \mathrm{~mm}$. longæ, $3, \rightrightarrows \mathrm{mm}$. latæ, nervis parallelis, ad marginem et apice longe pilosie, dense breviter glanduloso-pubescentes. Bracteolæ similes, $11 \mathrm{~mm}$. longæ, 2.5 mm. latæ. Calycis laciniæ lineares, minute puberulæ, $.5-6 \times 1 \mathrm{~mm}$. subæquales. Flores flavi. Tubus c. $7 \mathrm{~mm}$. longus, basi $\mathbf{1 , 5}$, apice $\mathbf{2 , 5} \mathrm{mm}$. diam., glaber. Labium superum $12 \mathrm{~mm}$. longum, $7 \mathrm{~mm}$. in medio latum, apice 2 dentibus, $2 \mathrm{~mm}$. longis, $3 \mathrm{~mm}$. latis, instructum. Labıum inferum usque ad basin fere 3 lobum, lobis $11 \times 7 \mathrm{~mm}$., rotundatis. Filamenta $6 \mathrm{~mm}$. longa, antheræ $2 \mathrm{~mm}$. longæ, loculis æquialte affixis. Pollinis granula typica, $45 \times 36-38 \mu$. Ovarium $1 \mathrm{~mm}$. altum. Stylus $1: 3 \mathrm{~mm}$. longus. Capsula ignota.

Hab, in Mexico, in prov. Oaxaca, in distr. Nochistlan, prope El Parian : Seler n. I56̈. - Flor. : Dec.

Von der folgenden Art durch die Behaarung und die völlig verschiedenen Blütenstände sofort zu trennen. Hierher gehört auch ein als Siphonoglossa ramosa (Erst. bestimmtes Exemplar (Pringle Mexico 6279). Die (Erstedsche Art hat ganz andere Blüten.

C. (?) tetramerioides Lindau nov. spec. Caulis subtetragonus, breviter pubescens, tum glabratus pilis deciduis punctatus, epidermide solvente. Folia petiolis 4 -5ٌ mm. longis, tenuibus, puberulis oblonga utrinque angustata, apice mucronata, usque ad $35 \times 7 \mathrm{~mm}$., puberula, cystolithis vix conspicuis. Spicæ terminales, sessiles, folia 1-2 plo superantes, tenues, imbricatæ. Bracteæ lanceolatæ, acutæ, $9 \times 15$ mm., margine et apice BULL. HERB. BOIss., août 1899. 
longe pubescentes, præterea ninute glandulosa. Bracteolæ similes, $8 \times 1 \mathrm{~mm}$. Calycis laciniæ lanceolatæ, subæquales, 3-3,5 mm. longæ, a pice pilis patentibus instructæ. Flores flavido-albi. Tubus c. :f mm. longus, basi 1, apice $2 \mathrm{~mm}$. diam. Labium superum $8 \mathrm{~mm}$. longum, in medio $4 \mathrm{~mm}$. latum, apice integrum. Labium inferum lobis 3, linguiformibus, $8 \mathrm{~mm}$. longis, $4 \mathrm{~mm}$. latis formatum. Filamenta こ̌ mm. Ionga. Antherarum loculi subaquialte affixi, $2 \mathrm{~mm}$. longi, obtusi. Pollinis granula typica, $42 \times 30 \mu$. Ovarium $1 \mathrm{~mm}$., stylus $13 \mathrm{~mm}$. longa. Capsula $6 \mathrm{~mm}$. longa, $2 \mathrm{~mm}$. lata, usque ad $1 / \mathrm{s}$ longit. stipitata, glabra, 4 sperma. Semina $1 \mathrm{~mm}$. diam., scrobiculata.

IIab. in Mexico, in prov. Oaxaca, in distr. Yauhtepec, ad Rancho de los Pichones in valleculis silvaticis aridis ad flumen Tehuantepec : Seler n. 1632. Flor. et fruct. : Jan.

Die beiden vorstehend beschriebenen Arten stelle ich nur mit Vorbehalt zu Cardiacunthus. Von den Gattungen der Odontonemince können nur Siphonoglossa und Cardiacrentlues in Betraclit kommen. Beide Gattungen unterscheiden sich durch die Form der Blumenkrone. Wảhrend bei ersterer der Tubus kaum erweitert, cylindrisch und ziemlich lang ist, stellt derselbe bei der letzteren eine kurze sich nach oben allmählich erweiternde Röhre dar. Die Form der Corolle würde nun am ehesten für Cardiacchthus passen, gegen eine Zuordnung sprechen aber die ährenförmigen Blütenstände. Dieses Merkmal würde auch für Siplionoglossa nicht recht zutreffen. Ich könnte nun eine neue Gattung aufstellen, die mit Cardiacantleus in der Krone übereinstimmen, sich aber durch die Blütenstände unterscheiden würde. Es ist aber besser die Zahl der Gattungen vorläufig nicht zu vermehren, da eine genauere Durcharbeitung dieser Gruppe jedenfalis ganz andere Gattungsbegrenzungen zu Tage fürdern wird, als bisher. Massgebend sind jetzt für die Abgrenzung Form der Corolle und die Blütenstände; wie weit aber letzteres Merkmal sich überhaupt zur Gattungsdefinition eignet, lässt sich vorläufig nicht entscheiden

Justicia Clinopodium Gray in Proc. An. Ac. Arts and Sc. XXXII. 1897, p. 30't $(=J$. patenti-ciliaia Lindan in Bull. Herb. Boiss. 1897, p. 673).

Hab. in Mex., in prov. Chiapas in pratis iuxta Comitan : Sel. n. 308'. Flor. : Aug.

$J$. (Dianthera) spec.

Hah. in Mex., in prov. Chiapas, in distr. Tuxtla ad rivulum in Hac. Petapa : Sel. 1. 1966. - Flor, : Febr.

Justicia spec. nim. juvenil.

IIab, in Mex, in prov. S. Luis Potosi, in distr. Ciudad del Maiz, prope Gallinas: Sel. n. 717. - Alabastr. juvenilia : Febr.

Jacobinia tinctoria OErst.

Vulg. : "flor de tinta ".

Ilab. in Mex., in prov. Chiapas, culta in Comitan : Sel. n. 2603̈. - Flor. : Mart. Beloperone ramulosa Morong.

Hab. in Honduras in ruinis al Copan : Sel. n. 3347. - Flor. : Jan.

B. violacea Planch, et Lind.

Hal, in Guatemala in fruticetis ad Chimaltenango : Sel. n. 2988, - Flor. : Sept. 
CAPRIFOLIACEE III., det. P. Græbner et Th. Lesener.

Fiburnum glabratum H. B. K.

Hab. in Mexico, in prov. Chiapas, in distr. Chilon, in montibus inter Oxchuc et San Martin et in Guatemala, in dept. La Antigua in valle silvatica et in agris ad San Lucas : S e I. n. 2I5I et 2413. - Flor. : Mart. et Oet.

r. triphyllum Benth.

Hab. in Guatemala, in dept. Huehuetenango, in clivo supra Jacaltenango : Sel. n. 2639. - Flor. : Apr.

\section{Sambucus Mexicana Presl.}

Vulg. : "sauco".

Hab. in Mexico, in prov. Chiapas in distr. centrali in silva montana iuxta Cinacantan et ad Huitztan, et in Guatemala in dept. Huehuetenango, in silva ad Todos Ios Santos : Sel. n. 2140, 22I2, 2962. - Flor. : Mart. ; fruct. : Jun.

(Fortsetzung folgt.) 



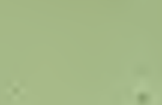

-58 


\section{BULLETIN \\ J)E. \\ L'HERBIEP BOISSIER}

SOOS T.A DIRECTION DE

\section{EUGENE AUTRAN}

Conservateur de I'Ilerlier.

\section{Tome VII. 1899.}

Ce Bullelin renferme des travanx originanx, des notes, etc.. de botanique syslématiquıe générale. II parait à éporques indéterninées.

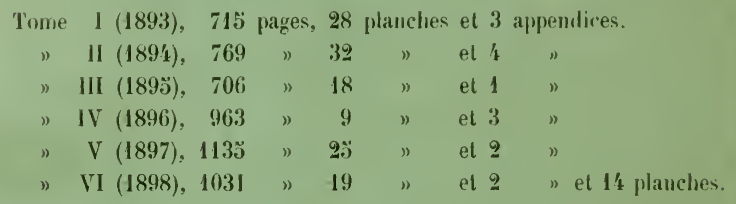

\section{Prix de l'Abonnement}

15 francs pals an pour la Sulsse. - 20 francs par an pour l.'Fitranger.

Les abonnements sont recus à I'HERRier BOISSIER, à CHAMBESY près Gedère (Suisse).

\section{(D) IBNIEIR VATION}

Les anleurs des travanx insèrés dans le Bulletin de l'llerlier Boissier. ont droil gratuilement a trente exemplaires en tirage a part.

Ancume livraison nest vendue séparémeut. 




Univesiy of

Connecticut

Libraries 
